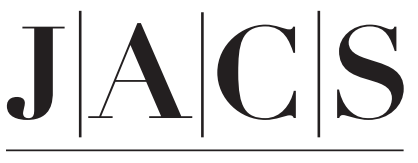

A R T I C L E S

Published on Web 02/01/2007

\title{
Modeling the 2-His-1-Carboxylate Facial Triad: Iron-Catecholato Complexes as Structural and Functional Models of the Extradiol Cleaving Dioxygenases
}

\author{
Pieter C. A. Bruijnincx, ${ }^{\dagger}$ Martin Lutz, ${ }^{\ddagger}$ Anthony L. Spek, ${ }^{\perp, \ddagger}$ Wilfred R. Hagen,, \\ Bert M. Weckhuysen," Gerard van Koten, ${ }^{\dagger}$ and Robertus J. M. Klein Gebbink*, ${ }^{\star}$ \\ Contribution from the Organic Chemistry and Catalysis Group, Faculty of Science, Utrecht \\ University, Padualaan 8, 3584 CH Utrecht, The Netherlands, Bijvoet Center for Biomolecular \\ Research, Crystal and Structural Chemistry Group, Faculty of Science, Utrecht University, \\ Padualaan 8, 3584 CH Utrecht, The Netherlands, Department of Biotechnology, Delft University \\ of Technology, Julianalaan 67, 2628 BC Delft, The Netherlands, and Inorganic Chemistry and \\ Catalysis Group, Faculty of Science, Utrecht University, Sorbonnelaan 16, 3584 CA Utrecht, \\ The Netherlands
}

Received July 6, 2006; E-mail: r.j.m.kleingebbink@chem.uu.nl

\begin{abstract}
Mononuclear iron(II) - and iron(III) - catecholato complexes with three members of a new 3,3bis(1-alkylimidazol-2-yl)propionate ligand family have been synthesized as models of the active sites of the extradiol cleaving catechol dioxygenases. These enzymes are part of the superfamily of dioxygenactivating mononuclear non-heme iron enzymes that feature the so-called 2-His-1-carboxylate facial triad. The tridentate, tripodal, and monoanionic ligands used in this study include the biologically relevant carboxylate and imidazole donor groups. The structure of the mononuclear iron(III)-tetrachlorocatecholato complex $\left[\mathrm{Fe}(\mathrm{L} 3)(\mathrm{tcc})\left(\mathrm{H}_{2} \mathrm{O}\right)\right]$ was determined by single-crystal X-ray diffraction, which shows a facial $\mathrm{N}, \mathrm{N}, \mathrm{O}$ capping mode of the ligand. For the first time, a mononuclear iron complex has been synthesized, which is facially capped by a ligand offering a tridentate $N_{\mathrm{im}}, N_{\mathrm{im}}, O_{\text {carb }}$ donor set, identical to the endogenous ligands of the 2-His-1-carboxylate facial triad. The iron complexes are five-coordinate in noncoordinating media, and the vacant coordination site is accessible for Lewis bases, e.g., pyridine, or small molecules such as dioxygen. The iron(II)-catecholato complexes react with dioxygen in two steps. In the first reaction the iron(II)-catecholato complexes rapidly convert to the corresponding iron(III) complexes, which then, in a second slow reaction, exhibit both oxidative cleavage and auto-oxidation of the substrate. Extradiol and intradiol cleavage are observed in noncoordinating solvents. The addition of a proton donor results in an increase in extradiol cleavage. The complexes add a new example to the small group of synthetic iron complexes capable of eliciting extradiol-type cleavage and provide more insight into the factors determining the regioselectivity of the enzymes.
\end{abstract}

\section{Introduction}

Extradiol cleaving catechol dioxygenases catalyze the oxidative cleavage of catechols at the aromatic $\mathrm{C}-\mathrm{C}$ bond adjacent to the catechol oxygens. ${ }^{1-3}$ These enzymes are part of a superfamily of enzymes that share a common structural motif at the active site, the so-called 2-His-1-carboxylate facial triad. ${ }^{4-6}$ Over the past decade, this structural motif has emerged

\footnotetext{
Organic Chemistry and Catalysis Group, Utrecht University.

Crystal and Structural Chemistry Group, Utrecht University.

$\S$ Delft University of Technology.

"Inorganic Chemistry and Catalysis Group, Utrecht University.

${ }^{\perp}$ To whom correspondence pertaining to crystallographic studies should be addressed. E-mail: a.1.spek@chem.uu.nl. Phone: +31-30-2532538. Fax: $+31-30-2533940$.

(1) Costas, M.; Mehn, M. P.; Jensen, M. P.; Que, L., Jr. Chem. Rev. 2004, 104, 939-986.

(2) Bugg, T. D. H. Tetrahedron 2003, 59, 7075-7101.

(3) Bugg, T. D. H.; Lin, G. Chem. Commun. 2001, 941-952.

(4) Hegg, E. L.; Que, L., Jr. Eur. J. Biochem. 1997, 250, 625-629.

(5) Que, L., Jr. Nat. Struct. Biol. 2000, 7, 625-629.

10.1021/ja064816x CCC: $\$ 37.00$ @ 2007 American Chemical Society
}

as a new common platform for dioxygen activation in biology. ${ }^{1,7}$ It consists of a mononuclear non-heme iron(II) center, which is coordinated by three endogenous ligands (two His and one Glu or Asp) in a facial manner, thereby leaving the other three coordination sites vacant and available for the binding of exogenous ligands such as dioxygen, substrate, and or cofactor (Figure 1). 1,5,7 The flexibility in coordination chemistry at the metal center is reflected in the stunningly diverse oxidative transformations that the enzymes of this superfamily catalyze, and new types of reactivity variations of this platform keep being discovered. ${ }^{8,9}$ The reactivity of these enzymes ranges from the

(6) Solomon, E. I.; Brunold, T. C.; Davis, M. I.; Kernsley, J. N.; Lee, S-K.; Lehnert, N.; Neese, F.; Skulan, A. J.; Yang, Y-S.; Zhou, J. Chem. Rev 2000, 100, 235-349.

(7) Koehntop, K. D.; Emerson, J. P.; Que, L., Jr. J. Biol. Inorg. Chem. 2005, 10, 87-93.

(8) Higgins, L. J.; Yan, F.; Liu, P.; Liu, H-W.; Drennan, C. L. Nature 2005, $437,838-844$

(9) Vaillancourt, F. H.; Yeh, E.; Vosburg, D. A.; O'Connor, S. E.; Walsh, C. T. Nature 2005, 436, 1191-1194. 


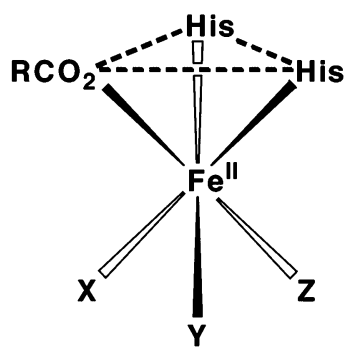

Figure 1. 2-His-1-carboxylate facial triad and ligands $\mathbf{L 1}, \mathbf{L 2}$, and $\mathbf{L 3}$.

biosynthesis of isopenicillins via heterocyclic ring formation ${ }^{10,11}$ to the cis-dihydroxylation of arene double bonds. ${ }^{12,13}$

Many studies have been devoted to the structural and functional modeling of this superfamily of enzymes. The most prominent polydentate ligands that have been studied in this respect are the tpa, bpmcn, ${ }^{14-21}\left(\mathrm{Me}_{3^{-}}\right) \operatorname{tacn},{ }^{19,22,23}$ and $\mathrm{Tp} \mathrm{p}^{\mathrm{R}, \mathrm{R}^{\prime} 24-28}$ ligand systems. ${ }^{29}$ Indeed, impressive results have been reported in mimicking both the structural and/or functional features of the enzymes under scrutiny. However, the ligands employed in these studies provide the metal center with an all $N$-donor set that does not accurately reflect the $N_{\mathrm{im}}, N_{\mathrm{im}}, O_{\text {carb }}$ ligand environment found at the active site of the enzymes. For this reason, attention has shifted to the development of mixed ligand systems. ${ }^{30-32}$ In order to more closely mimic the 2-His-1carboxylate facial triad, models should preferably contain tridentate, tripodal $N, N, O$ ligands with a monoanionic carboxylate group. Such ligands are rare, and only very few such $N, N, O$ iron complexes have been reported; see, e.g., the bispyrazolylacetates studied by Burzlaff et al. ${ }^{30,31}$ We recently reported the

(10) Burzlaff, N.; Rutledge, P. J.; Clifton, I. J.; Hensgens, C. M. H.; Pickford, M.; Adlington, R. M.; Roach, P. L.; Baldwin, J. E. Nature 1999, 401, 721724.

(11) Roach, P. L.; Clifton, I. J.; Hensgens, C. M. H.; Shibata, N.; Schofield, C. J.; Hajdu, J.; Baldwin, J. E. Nature 1997, 387, 827-830.

(12) Carredona, E.; Karlsson, A.; Kauppi, B.; Choudhury, D.; Parales, R. E.; Parales, J. V.; Lee, K.; Gibson, D. T.; Eklund, H.; Ramaswamy, S. J. Mol. Biol. 2000, 296, 701-712.

(13) Karlsson, A.; Parales, J. V.; Parales, R. E.; Gibson, D. T.; Eklund, H.; Ramaswamy, S. Science 2003, 299, 1039-1041.

(14) Chen, K.; Costas, M.; Kim, J.; Tipton, A. K.; Que, L., Jr. J. Am. Chem. Soc. 2002, 124, 3026-3035.

(15) Chen, K.; Costas, M.; Que, L., Jr. J. Chem. Soc., Dalton Trans. 2002, 672679

(16) Chiou, Y.-M.; Que, L., Jr. Inorg. Chem. 1995, 34, 3577-3578

(17) Chiou, Y.-M.; Que, L., Jr. J. Am. Chem. Soc. 1995, 117, 3999-4013.

(18) Costas, M.; Que, L., Jr. Angew. Chem., Int. Ed. 2002, 41, 2179-2181.

(19) Jo, D.-H.; Chiou, Y.-M.; Que, L., Jr. Inorg. Chem. 2001, 40, 3181-3190.

(20) Oh, N. Y.; Suh, Y.; Park, M. J.; Seo, M. S.; Kim, J.; Nam, W. Angew. Chem., Int. Ed. 2005, 44, 4235-4239.

(21) Park, M. J.; Lee, J.; Suh, Y.; Kim, J.; Nam, W. J. Am. Chem. Soc. 2006 $128,2630-2634$

(22) Ito, M.; Que, L., Jr. Angew, Chem Int Ed Engl 1997, 36, 1342-1344.

(23) Lin, G.; Reid, G.; Bugg, T. D. H. J. Am. Chem. Soc. 2001, 123, 50305039 .

(24) Hegg, E. L.; Ho, R. Y. N.; Que, L., Jr. J. Am. Chem. Soc. 1999, 121, $1972-$ 1973

(25) Kitajima, N.; Tamura, N.; Amagai, H.; Fukui, H.; Moro-oka, Y.; Mizutani, Y.; Kitagawa, T.; Mathur, R.; Heerwegh, K.; Reed, C. A.; Randall, C. R.; Que, L., Jr.; Tatsumi, K. J. Am. Chem. Soc. 1994, 116, 9071-9085.

(26) Kitajima, N.; Tolman, W. B. Prog. Inorg. Chem. 1995, 43, 419-531.

(27) Mehn, M. P.; Fujisawa, K.; Hegg, E. L.; Que, L., Jr. J. Am. Chem. Soc. 2003, 125, 7828-7842

(28) Ogihara, T.; Hikichi, S.; Akita, M.; Moro-oka, Y. Inorg. Chem. 1998, 37, $2614-2615$

(29) Abbreviations used in this paper: tpa (tris(2-pyridylmethyl)amine), bpmcn ( $N, N$-bis-(2-pyridylmethyl)- $N^{\prime}, N^{\prime}$-dimethyl-1,2-cyclohexanediamine), $\mathrm{Tp}^{\mathrm{R}, \mathrm{R}}$ (hydrotris (3,5-R, $\mathrm{R}^{\prime}$-pyrazol)borato), tacn (1,4,7-triazacyclononane), $\mathrm{Me}_{3}-$ tacn $\left(N, N^{\prime}, N^{\prime \prime}\right.$-trimethyl-1,4,7-triazacyclononane), bpg (bis(picolyl)glycine), bpia (((1-methylimidazol-2-yl)methyl)(bis-(2-pyridyl)methyl)amine), bpba ((benzimidazol-2-yl)methyl)(bis-(2-pyridyl)methyl)amine).

(30) Beck, A.; Barth, A.; Hubner, E.; Burzlaff, N. Inorg. Chem. 2003, 42, 71827188

(31) Beck, A.; Weibert, B.; Burzlaff, N. Eur. J. Inorg. Chem. 2001, 521-527.

(32) Oldenburg, P. D.; Shteinman, A. A.; Que, L., Jr. J. Am. Chem. Soc. 2005, $127,15673-15674$.
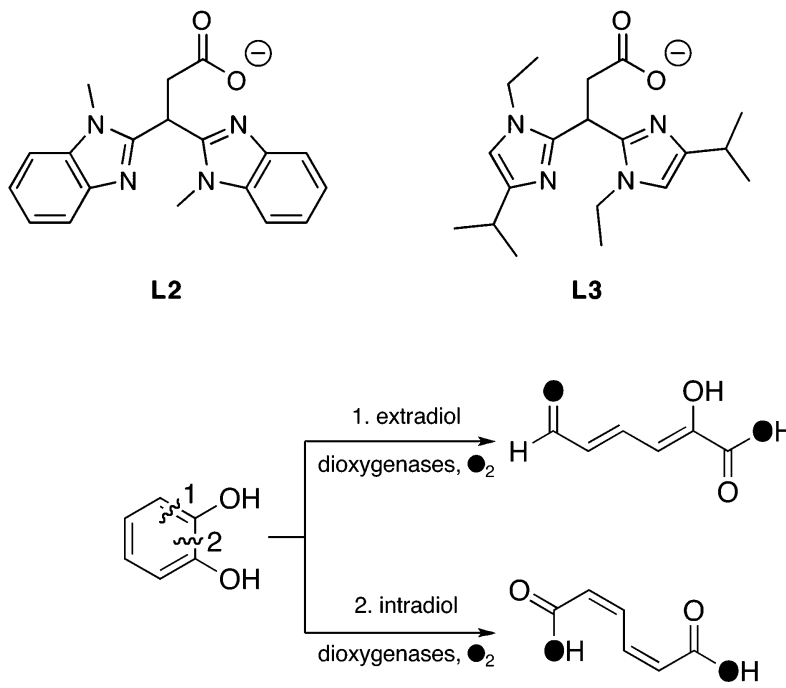

Figure 2. Catechol cleavage by the extradiol and intradiol dioxygenases.

synthesis and facial capping potential of the bis(1-alkylimidazol2-yl)propionate framework, a family of monoanionic, tridentate, tripodal ligands that include the biologically relevant carboxylate and imidazole donor groups. ${ }^{33-35}$ To examine their use as mimics of the 2-His-1-carboxylate facial triad superfamily, we set out to study these ligands and their iron complexes with respect to the extradiol cleaving catechol dioxygenases (Figure $1)$.

The oxidative cleavage of catechols is a key step in the biodegradation of aromatic compounds. In general, the responsible catechol dioxygenases can be divided into two classes, based on the position of the catechol ring cleavage (Figure 2). ${ }^{1}$ The extradiol dioxygenases represent the more common metabolic pathway in which the $\mathrm{C}-\mathrm{C}$ bond adjacent to the catechol oxygens is cleaved. These enzymes are characterized by a nonheme iron(II) active site ligated by the 2-His-1-carboxylate facial triad. ${ }^{4,5,7}$ The intradiol dioxygenases use a non-heme iron(III) cofactor with a $\mathrm{His}_{2} \mathrm{Tyr}_{2}$ donor set around the metal center and cleave the $\mathrm{C}-\mathrm{C}$ bond of the enediol functionality. ${ }^{36}$

The mechanisms by which these two types of enzymes catalyze the regioselective oxidative ring cleavage are not fully understood. How the enzymes differentiate between the two possible reaction pathways and what decisive factors control the reactivity are currently under active investigation. ${ }^{1,2,37,38}$

To address these questions, the use of accurate model complexes can give more insight into the factors governing the regioselectivity of the cleavage. Since the enzymes utilize an ordered mechanism with substrate binding before dioxygen

(33) Bruijnincx, P. C. A.; Lutz, M.; Spek, A. L.; van Faassen, E. L.; Weckhuysen, B. M.; van Koten, G.; Klein Gebbink, R. J. M. Eur. J. Inorg. Chem. 2005 779-787.

(34) Kervinen, K.; Bruijnincx, P. C. A.; Beale, A. M.; Mesu, J. G.; van Koten, G.; Klein Gebbink, R. J. M.; Weckhuysen, B. M. J. Am. Chem. Soc. 2006 $128,3208-3217$

(35) The synthesis of ligand $\mathbf{L} 1$ was independently reported by Burzlaff, et al. Peters, L.; Hübner, E.; Burzlaff, N. J. Organomet. Chem. 2005, 690, 20092016.

(36) Ohlendorf, D. H.; Lipscomb, J. D.; Weber, P. C. Nature 1988, 336, 403405.

(37) Siegbahn, P. E. M.; Haeffner, F. J. Am. Chem. Soc. 2004, 126, 89198932.

(38) Vetting, M. W.; Wackett, L. P.; Que, L., Jr.; Lipscomb, J. D.; Ohlendorf, D. H. J. Bacteriol. 2004, 186, 1945-1958. 
Chart 1. Iron(II)- and Iron(III)-Catecholato Complexes (see Figure 1 for the Structures of L1, L2, and L3)

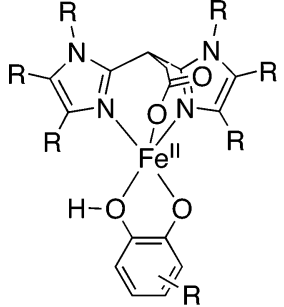

$\left[\mathrm{Fe}^{\prime \prime}(\mathbf{L 1})(\mathrm{Htcc})\right](\mathbf{1})$ $\left[\mathrm{Fe}{ }^{\|}(\mathrm{L2})(\mathrm{HtcC})\right](2)$ $\left[\mathrm{Fe}^{\prime \prime}(\mathrm{L} \mathbf{3})(\mathrm{HtcC})\right]$ (3)

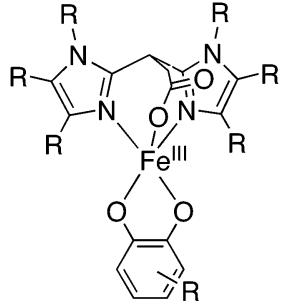

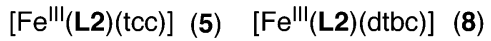
$\left[\mathrm{Fe}^{\prime \prime \prime}(\mathrm{L3})(\mathrm{tcc})\right](6) \quad\left[\mathrm{Fe}^{\mathrm{III}}(\mathrm{L} 3)(\mathrm{dtbc})\right](9)$

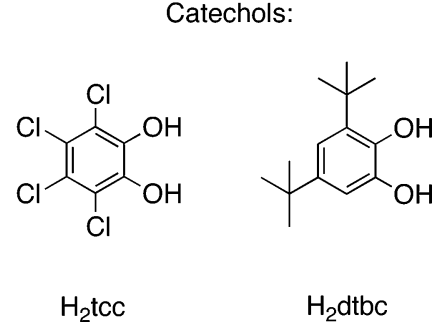

$\mathrm{H}_{2} \mathrm{tcc}$

$\mathrm{H}_{2} \mathrm{dtbc}$ activation, ${ }^{6,39}$ isolated iron-catecholato complexes serve as an excellent starting point to model the chemistry of this enzymesubstrate complex. Most of the reported mimics of the catechol dioxygenases make use of tetradentate ligands and display intradiol activity. ${ }^{1,2,40}$ Only a few iron complexes have been reported to give extradiol type cleavage products. ${ }^{23,28,41-44}$ The system reported by Funabiki, a mixture of $\mathrm{FeCl}_{2}$ or $\mathrm{FeCl}_{3}$ with pyridine/bipyridine, was the first example of a functional mimic of the extradiol dioxygenases. ${ }^{45}$ Que et al. communicated the quantitative extradiol cleavage of an isolated $\left[\mathrm{Fe}^{\mathrm{III}}(\mathrm{Cl})(\mathrm{dtbc})\right.$ $\left(\mathrm{Me}_{3}\right.$-tacn) $]$ complex $(\mathrm{dtbc}=3,5$-di-tert-butylcatecholate dianion), ${ }^{43}$ and along a similar vein, Bugg et al. reported the extradiol type cleavage of catechol using mixtures of tacn, pyridine, and either $\mathrm{FeCl}_{2}$ or $\mathrm{FeCl}_{3} \cdot{ }^{23}$ In both cases, the use of tridentate ligands that facially cap the metal center was of prime importance. There are, however, no examples reported to date of iron complexes with a mixed donor ligand, which would more accurately reflect the active site of the enzymes, that elicit extradiol type cleavage.

We report here the first mononuclear iron(II/III)-catecholato complexes with tridentate ligands of the new bis(1-alkylimidazol-2-yl)propionate ligand family as structural and functional mimics of the extradiol cleaving catechol dioxygenases. The synthesis and structural characterization of these complexes, as well as their dioxygen reactivity and product selectivity, will be discussed. These studies provide further insight into the factors governing the observed cleavage pathways of the extradiol catechol cleaving enzymes.

\section{Results}

Synthesis of Ligands L1 $-\mathbf{L} 3$. The potassium salts of ligands L1 (3,3-bis(1-methylimidazol-2-yl)propionate) and L2 (3,3-bis(1-methylbenzimidazol-2-yl)propionate) were synthesized according to the general synthetic route previously developed by our group for substituted 3,3-bis(1-alkylimidazol-2-yl)propionates. ${ }^{33}[\mathrm{~K}(\mathbf{L} \mathbf{3})](\mathbf{L 3}=3$,3-bis(1-ethyl-4-isopropylimidazol-

(39) Lipscomb, J. D.; Orville, A. Metal Ions in Biological Systems; Marcel Dekker: New York, 1992; Vol. 28, pp 243-298.

(40) Yamahara, R.; Ogo, S.; Masuda, H.; Watanabe, Y. J. Inorg. Biochem. 2002 $88,284-294$.

(41) Dei, A.; Gatteschi, D.; Pardi, L. Inorg. Chem. 1993, 32, 1389-1395.

(42) Funabiki, T.; Mizoguchi, A.; Sugimoto, T.; Tada, S.; Tsugi, M.; Sakamoto, H.; Yoshida, S. J. Am. Chem. Soc. 1986, 108, 2921-2932.

(43) Jo, D.-H.; Que, L., Jr. Angew. Chem., Int. Ed. 2000, 39, 4284-4287.

(44) Raffard, N.; Carina, R.; Simaan, A. J.; Sainton, J.; Rivière, E.; Tchertanov, L.; Bourcier, S.; Bouchoux, G.; Delroisse, M.; Banse, F.; Girerd, J.-J. Eur. J. Inorg. Chem. 2001, 2249-2254.

(45) Funabiki, T.; Mizoguchi, A.; Sugimoto, T.; Tada, S.; Tsuji, M.; Sakamoto, H.; Yoshida, S. J. Am. Chem. Soc. 1986, 108, 2921-2932. 2-yl)propionate) is a new member of this ligand family and was synthesized according to the same synthetic strategy in four steps, starting from 1-ethyl-4-isopropylimidazole. The synthesis of $\mathbf{L 3}$ is depicted in Scheme S1 of the Supporting Information. $\mathbf{L 3}$ is a sterically more demanding $N, N, O$ ligand, and the organic substituents on the imidazole rings increase the solubility of its metal complexes in apolar and noncoordinating solvents.

Synthesis and Characterization of Iron(II)-Catecholato Complexes. Fe(II) - catecholato complexes with three tridentate, monoanionic $N, N, O$ ligands $\mathbf{L 1}, \mathbf{L} 2$, and $\mathbf{L 3}$ and two differently substituted catechols $\left(\mathrm{H}_{2} \mathrm{tcc}\right.$ and $\left.\mathrm{H}_{2} \mathrm{dtbc}\right)$ were synthesized (Chart 1). Complexes of the type $\left[\mathrm{Fe}^{\mathrm{II}}(\mathbf{L})(\mathrm{Htcc})\right](\mathbf{1}-\mathbf{3})$ were synthesized by the addition of a methanolic solution of equimolar amounts of $\mathrm{H}_{2} \mathrm{tcc}$ and $\mathrm{Et}_{3} \mathrm{~N}$ to a methanolic solution containing equimolar amounts of $\mathrm{Fe}(\mathrm{OTf})_{2} \cdot 2 \mathrm{MeCN}$ and $\mathrm{K}[\mathbf{L}]$ under argon. Upon addition of the catechol/base solution an immediate and drastic color change from yellow to deep red-purple was observed. These products are sensitive toward air. The compounds could be isolated as purple $(\mathbf{1}, \mathbf{2})$ or burgundy-red powders (3) in $40-72 \%$ yield. The complexes are obtained as neutral species of the composition $\left[\mathrm{Fe}^{\mathrm{II}}(\mathbf{L})(\mathrm{Htcc})\right]$, as both the tridentate ligand and a monoanionic catecholato ligand neutralize the +2 charge of the ferrous ion. The $\left[\mathrm{Fe}^{\mathrm{II}}(\mathbf{L})(\mathrm{Htcc})\right]$ complexes 1-3 are paramagnetic, and their solution magnetic moments were determined by the Evans' NMR method. ${ }^{46,47}$ The iron(II) complexes afforded magnetic moments in the range 5.2-5.3 $\mu_{\mathrm{B}}$, consistent with a high spin configuration of the ferrous complexes. Elemental analyses confirm the composition of the five-coordinate iron(II) complexes. The ESI-MS spectra of the complexes show one predominant peak corresponding to the mononuclear, one-electron oxidized $\left[\mathrm{Fe}^{\mathrm{III}}(\mathbf{L})(\mathrm{Htcc})\right]^{+}$ion with expected isotope pattern. Since the samples were briefly handled in air before the measurement, we also recorded ESI-MS spectra of the complexes under anaerobic conditions and observed similar spectra with the same $\left[\mathrm{Fe}^{\mathrm{III}}(\mathbf{L})(\mathrm{Htcc})\right]^{+}$ion peak. The oxidation of the complex is a consequence of the conditions of the mass spectrometric measurement. The electronic spectra of these complexes are characterized by one single absorption band in the visible region at approximately $600 \mathrm{~nm}$, accounting for their purplish color (Table 1). Whereas the $\left[\mathrm{Fe}^{\mathrm{II}}(\mathbf{L})(\mathrm{Htcc})\right]$ complexes are fairly stable and can be isolated, the analogous $\left[\mathrm{Fe}^{\mathrm{II}}(\mathbf{L})(\mathrm{Hdtbc})\right]$ complexes were found to be extremely $\mathrm{O}_{2}-$ sensitive. These complexes were synthesized in situ following

(46) Britovsek, G. J. P.; Gibson, V. C.; Spitzmesser, S. K.; Tellmann, K. P. White, A. J. P.; Williams, D. J. J. Chem. Soc., Dalton Trans. 2002, 11591171 
Table 1. Absorption Maxima of Bands Observed in the UV-vis Spectra of the Iron-Catecholato Complexes $\left[\lambda_{\max },\left(\epsilon\left[\mathrm{M}^{-1} \mathrm{~cm}^{-1}\right]\right)\right]$

\begin{tabular}{cccc}
\hline & L1 & L2 & L3 \\
\hline \multirow{2}{*}{$\mathrm{Fe}^{\mathrm{II}}-\mathrm{Htcc}$} & $\mathbf{( 1 )}$ & $(\mathbf{2})$ & $(\mathbf{3})$ \\
& $597(3300)$ & $603(2400)$ & $606(5000)$ \\
$\mathrm{Fe}^{\mathrm{III}}-\mathrm{tcc}$ & $\mathbf{( 4 )}$ & $(\mathbf{5})$ & $(\mathbf{6})$ \\
& $490(1600)$ & $480(1400)$ & $492(1600)$ \\
& $626(2300)$ & $663(2100)$ & $667(2400)$ \\
$\mathrm{Fe}^{\mathrm{III}}-\mathrm{dtbc}$ & $(\mathbf{7})$ & $(\mathbf{8})$ & $(\mathbf{9})$ \\
& $790(2000)$ & $504(2900)$ & $521(2400)$ \\
& $790(3000)$ & $822(4200)$ & $807(3200)$ \\
\hline
\end{tabular}

Table 2. EPR Data for Complexes 4-9a

\begin{tabular}{ccc}
\hline complex & g values $^{b}$ & $E / D$ \\
\hline$\left[\mathrm{Fe}^{\mathrm{III}}(\mathbf{L 1})(\mathrm{tcc})\right](\mathbf{4})$ & $4.5,4.2,4.0$ & 0.290 \\
{$\left[\mathrm{Fe}^{\mathrm{III}}(\mathbf{L 2})(\mathrm{tcc})\right](\mathbf{5})$} & $8.0,5.7,3.7$ & 0.097 \\
{$\left[\mathrm{Fe}^{\mathrm{III}}(\mathbf{L 3})(\mathrm{tcc})\right](\mathbf{6})$} & $8.3,5.6,3.4$ & 0.117 \\
{$\left[\mathrm{Fe}^{\mathrm{III}}(\mathbf{L 1})(\mathrm{dtbc})\right](\mathbf{7})^{c}$} & $8.3,5.6,3.4$ & 0.117 \\
{$\left[\mathrm{Fe}^{\mathrm{III}}(\mathbf{L 2})(\mathrm{dtbc})\right](\mathbf{8})^{c}$} & $8.1,5.7,3.6$ & 0.104 \\
{$\left[\mathrm{Fe}^{\mathrm{III}}(\mathbf{L 3})(\mathrm{dtbc})\right](\mathbf{9})^{c}$} & $9.0,5.1,3.6$ & 0.190 \\
\hline
\end{tabular}

${ }^{a}$ EPR spectra were recorded on $2 \mathrm{mM}$ complex in frozen methanol solution at $15(\mathbf{4}, \mathbf{5}, \mathbf{7 - 9})$ and $22.5 \mathrm{~K}(\mathbf{6}) .{ }^{b}$ Effective $g$ values and rhombicities were determined with the program RHOMBO..$^{48}{ }^{c} g$ Values of the major species, a minor low-spin Fe(III) species is also observed ( $g$ $\approx 2.00,2.00,1.97)$; the minor species accounts in each case for $<10 \%$ of the total spin.

the same procedure as that described above, affording yellowbrown solutions. However, attempts to isolate these $\mathrm{Fe}(\mathrm{II})$ complexes failed, because of their extremely fast oxidation with dioxygen yielding the corresponding $\left[\mathrm{Fe}^{\mathrm{III}}(\mathbf{L})(\mathrm{dtbc})\right]$ complexes (vide infra).

Synthesis and Characterization of Iron(III) - Catecholato Complexes. $\left[\mathrm{Fe}^{\mathrm{III}}(\mathbf{L})(\mathrm{tcc})\right]$ and $\left[\mathrm{Fe}^{\mathrm{III}}(\mathbf{L})(\mathrm{dtbc})\right]$ complexes $(\mathbf{4}-$ 9) were synthesized by the addition of a methanolic catechol solution with 2 equiv of $\mathrm{Et}_{3} \mathrm{~N}$ to a methanolic solution containing equimolar amounts of $\mathrm{Fe}\left(\mathrm{NO}_{3}\right)_{3} \cdot 9 \mathrm{H}_{2} \mathrm{O}$ and $\mathrm{K}(\mathbf{L})$ under argon. The red (L1, L2) or yellow (L3) solutions immediately turned dark blue in the case of the tcc complexes and dark purpleblue in the case of the dtbc complexes. The $\left[\mathrm{Fe}^{\mathrm{III}}(\mathbf{L})(\mathrm{tcc})\right]$ complexes 4-6 were isolated as air-stable blue-black powders. Although the $\left[\mathrm{Fe}^{\mathrm{III}}(\mathbf{L})(\mathrm{dtbc})\right]$ complexes $\mathbf{7 - 9}$ are still sensitive toward oxidation by air, they could nevertheless be isolated as purple-black powders. All complexes were obtained in good to excellent yields (72-95\%). Again, like the Fe(II) complexes, the complexes 4-9 were obtained as neutral, five-coordinate complexes, in which the monoanionic tridentate ligand and a dianionic, chelated catecholato ligand carry the negative charges. Complexes 4-9 exhibit EPR spectra indicating that these are all high-spin ferric complexes (data given in Table 2). The EPR spectra of $\left[\mathrm{Fe}^{\mathrm{III}}(\mathbf{L} \mathbf{3})(\mathrm{tcc})\right](\mathbf{6})$ and $\left[\mathrm{Fe}^{\mathrm{III}}(\mathbf{L} \mathbf{3})(\mathrm{dtbc})\right](\mathbf{9})$ are shown in Figure 3. The spectrum of $\left[\mathrm{Fe}^{\mathrm{III}}(\mathbf{L 3})(\mathrm{tcc})\right](\mathbf{6})$ is typical for an $S=5 / 2$ system $(E / D=0.117)$ with peaks at $8.3,5.4$, and 3.3 resulting from the ground and middle Kramers doublets. The signal at 4.3 can be assigned to a small rhombic ferric impurity. A similar spectrum is obtained for $\left[\mathrm{Fe}^{\mathrm{III}}(\mathbf{L} \mathbf{3})(\mathrm{dtbc})\right](\mathbf{9})$ with $g$ $=9.0,5.2$, and $3.9(E / D=0.190)$. The EPR envelope of 9 shows an additional feature possibly of a low-spin Fe(III) species ( $S=1 / 2, g=2.00,2.00$, and 1.97). This feature arises from a minority species, accounting for less than $10 \%$ of the total spin concentration according to spectral simulations.

(47) Evans, D. F. J. Chem. Soc. 1959, 2003-2005.

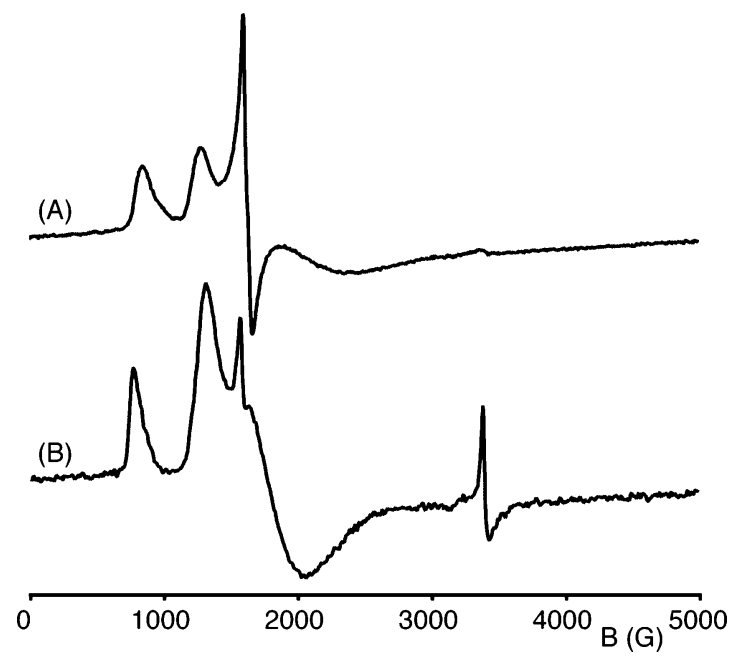

Figure 3. $\mathrm{X}$-band EPR spectra of $2 \mathrm{mM}\left[\mathrm{Fe}^{\mathrm{III}}(\mathbf{L 3})(\mathrm{tcc})\right](\mathbf{6})(\mathbf{A})$ and $\left[\mathrm{Fe}^{\mathrm{III}}-\right.$ $(\mathbf{L 3})(\mathrm{dtbc})]$ (9) (B) recorded in frozen methanol solution at 22.5 and $15 \mathrm{~K}$, respectively. Typical EPR measuring conditions: microwave frequency 9.63 $\mathrm{GHz}$, microwave power $0.5 \mathrm{mWatt}$, modulation amplitude $12.5 \mathrm{G}$, modulation frequency $100 \mathrm{kHz}$, and sweep width $5000 \mathrm{G}$.

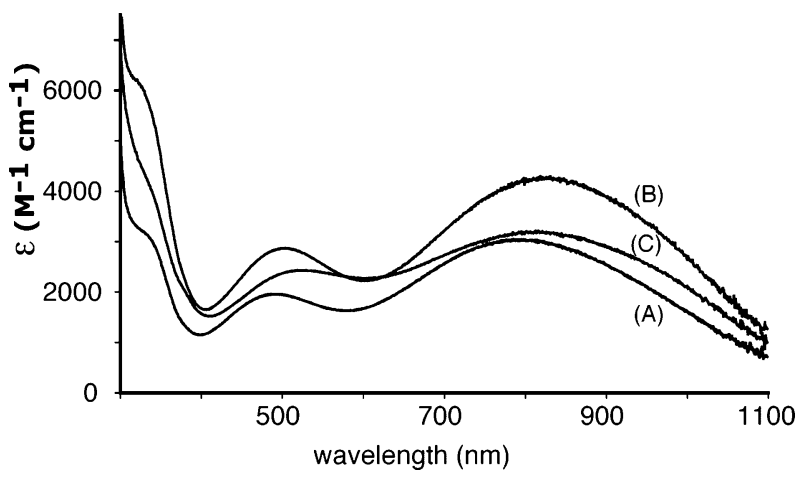

Figure 4. UV-vis absorption spectra of $\left[\mathrm{Fe}^{\mathrm{III}}(\mathbf{L 1})(\mathrm{dtbc})\right](7)(\mathrm{A}),\left[\mathrm{Fe}^{\mathrm{III}}\right.$ $(\mathbf{L 2})(\mathrm{dtbc})](\mathbf{8})(\mathrm{B})$, and $\left[\mathrm{Fe}^{\mathrm{III}}(\mathbf{L 3})(\mathrm{dtbc})\right](\mathbf{9})(\mathrm{C})$. All spectra were recorded in methanol solution.

The electronic spectra of the $\left[\mathrm{Fe}^{\mathrm{III}}(\mathbf{L})(\mathrm{dtbc})\right]$ complexes $(7-$ 9) in methanol are dominated by two moderately intense absorption bands in the 400-1100 nm region (Table 1, Figure 4). Que et al. showed that these bands are highly characteristic of catecholato-to-iron(III) charge-transfer bands and that the lower energy absorption can be correlated to the Lewis acidity of the Fe(III) metal center. ${ }^{49}$ In our case, the lower energy absorptions are quite blue-shifted compared to iron(III)catecholato complexes with $N$-polydentate ligands. They are found between 790 and $822 \mathrm{~nm}$ and reflect the reduced Lewis acidity arising from the coordination of a $N, N, O$ donor set involving the hard carboxylato-oxygen anion. Similar values $\left(\lambda_{\max }=520,788 \mathrm{~nm}\right)$ were reported for $\left[\mathrm{Fe}^{\mathrm{III}}(\mathrm{bpg})(\mathrm{dtbc})\right]$ in which the tetradentate bpg ligand also contains one carboxylate group. ${ }^{49}$

The $\left[\mathrm{Fe}^{\mathrm{III}}(\mathbf{L})(\mathrm{tcc})\right]$ complexes $(\mathbf{4}-\mathbf{6})$ display similar absorption spectra but exhibit a further blue-shift of the lower energy LMCT band to $626-667 \mathrm{~nm}$. The lower energy absorption band is reported to shift to higher energy as the substituents on the catecholate change from electron donating to electron withdraw-

(48) Hagen, W. R. Adv. Inorg. Chem. 1992, 38, 165-222

(49) Cox, D. D.; Benkovic, S. J.; Bloom, L. M.; Bradley, F. C.; Nelson, M. J.; Que, L., Jr.; Wallick, D. E. J. Am. Chem. Soc. 1988, 110, 2026-2032. 


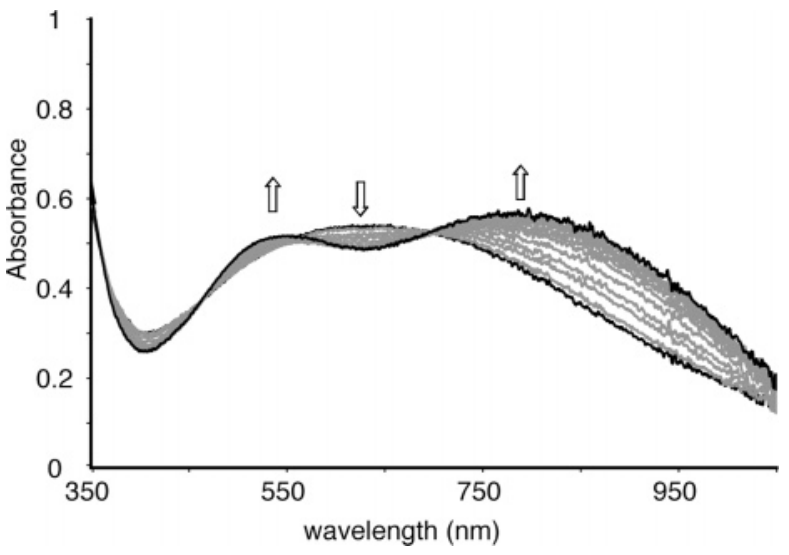

Figure 5. Titration of a solution of $\left[\mathrm{Fe}^{\mathrm{III}}(\mathbf{L} \mathbf{3})(\mathrm{dtbc})\right]$ in dichloromethane with pyridine. The features at 535 and $800 \mathrm{~nm}$ increase upon addition of pyridine $(0-500$ equiv)

ing, as is the case here ${ }^{49,50}$ Interestingly, in noncoordinating solvents such as dichloromethane, a broader, less resolved feature is observed for each of the $\left[\mathrm{Fe}^{\mathrm{III}}(\mathbf{L})(\mathrm{dtbc})\right]$ complexes; i.e., the two LMCT bands have broadened and are shifted toward each other. Upon titration of dichloromethane solutions of these complexes with pyridine, the two distinct LMCT bands are restored at 535 and $800 \mathrm{~nm}$, and after the addition of 500 equiv of pyridine a spectrum very similar to the spectrum recorded in pure methanol is observed (Figure 5). This spectral change is in each case accompanied by a distinct color change from blue to purple. The same titration experiments with pyridine of a methanolic solution of the $\left[\mathrm{Fe}^{\mathrm{III}}(\mathbf{L})(\mathrm{dtbc})\right]$ complexes did not result in a significant change. This data suggests that the Fe(III) complexes are five-coordinate, unsaturated complexes in noncoordinating media with a vacant coordination site accessible for binding of Lewis bases such as pyridine. In (weakly) coordinating solvents this vacant site is occupied by a solvent molecule. These findings correspond well with the observations made by Moro-oka et al., who reported that upon dissolution of the purple species $\left[\mathrm{Fe}^{\mathrm{III}}\left(\mathrm{Tp}^{i \mathrm{Pr} 2}\right)(\mathrm{dtbc})(\mathrm{MeCN})\right]$ in toluene, a blue solution with coordinatively unsaturated $\left[\mathrm{Fe}^{\mathrm{III}}\left(\mathrm{Tp}^{i \mathrm{Pr} 2}\right)(\mathrm{dtbc})\right]$ is obtained. ${ }^{28}$

Crystal Structure of $\left[\mathrm{Fe}(\mathrm{L3})(\mathrm{tcc})\left(\mathrm{H}_{2} \mathrm{O}\right)\right]$. Blue-purple crystals of $\mathbf{6}$ suitable for X-ray diffraction were obtained by slow evaporation of a dichloromethane/hexanes solution under ambient conditions. Upon crystallization, the complex picked up a water molecule and a six-coordinate iron complex is obtained. ${ }^{51}$ The molecular structure of $\mathbf{6}$ is depicted in Figure 6, with selected bond lengths and angles presented in Table 3 .

The iron(III) metal center in $\mathbf{6}$ is coordinated by the three donor atoms of the $N, N, O$ ligand. A chelated tetrachlorocatecholato ligand and a water molecule complete the distorted octahedral coordination sphere. The ligand thus provides a facial array of two imidazole $N_{\epsilon}$ donors and one $O$ donor of a monoanionic carboxylato ligand, identical to the facial motif encountered in the 2-His-1-carboxylate facial triad. The Fe$\mathrm{N} 11$ and $\mathrm{Fe}-\mathrm{N} 41$ bonds at 2.130(2) and 2.127(2) $\AA$ are identical within error, despite the different ligands positioned trans to the imidazole $N$ ligands. The $\mathrm{Fe}-\mathrm{N}_{\text {im }}$ bond lengths are longer

(50) Pascaly, M.; Duda, M.; Schweppe, F.; Zurlinden, K.; Müller, F. K.; Krebs, B. J. Chem. Soc., Dalton Trans. 2001, 828-837.

(51) A coordinated water molecule was present in three independent crystal structure determinations, of which the crystals were obtained from three different solvent combinations.

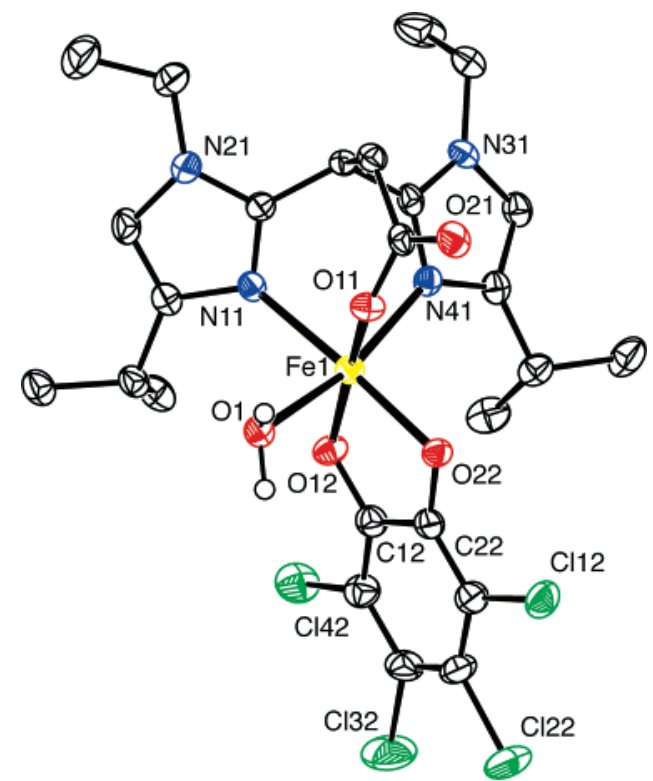

Figure 6. Molecular structure of $\left[\mathrm{Fe}(\mathbf{L 3})(\mathrm{tcc})\left(\mathrm{H}_{2} \mathrm{O}\right)\right](\mathbf{6})$ in the crystal. All hydrogen atoms except for those of the water molecule have been omitted for clarity. Displacement ellipsoids are drawn at the 50\% probability level.

Table 3. Selected Bond Lengths $(\AA)$ and Angles (deg) for 6

\begin{tabular}{lllllr}
\hline \multicolumn{5}{c}{ bond length } & \multicolumn{3}{c}{ angle } & angle \\
\hline $\mathrm{Fe} 1-\mathrm{N} 11$ & $2.130(2)$ & $\mathrm{O} 22-\mathrm{Fe} 1-\mathrm{N} 11$ & $177.02(7)$ & $\mathrm{N} 41-\mathrm{Fe} 1-\mathrm{O} 11$ & $88.03(8)$ \\
$\mathrm{Fe} 1-\mathrm{N} 41$ & $2.127(2)$ & $\mathrm{O} 11-\mathrm{Fe} 1-\mathrm{O} 12$ & $169.01(8)$ & $\mathrm{N} 41-\mathrm{Fe} 1-\mathrm{N} 11$ & $83.47(8)$ \\
$\mathrm{Fe} 1-\mathrm{O} 11$ & $1.9516(18)$ & $\mathrm{O} 1-\mathrm{Fe} 1-\mathrm{N} 41$ & $165.65(9)$ & $\mathrm{N} 41-\mathrm{Fe} 1-\mathrm{O} 12$ & $101.40(8)$ \\
$\mathrm{Fe} 1-\mathrm{O} 12$ & $1.9231(18)$ & & & $\mathrm{N} 41-\mathrm{Fe} 1-\mathrm{O} 22$ & $99.15(8)$ \\
$\mathrm{Fe} 1-\mathrm{O} 22$ & $2.0009(18)$ & & & & \\
$\mathrm{Fe} 1-\mathrm{O} 1$ & $2.143(2)$ & $\mathrm{O} 11-\mathrm{Fe} 1-\mathrm{O} 22$ & $90.40(7)$ & $\mathrm{O} 1-\mathrm{Fe} 1-\mathrm{O} 11$ & $81.16(9)$ \\
$\mathrm{C} 12-\mathrm{O} 12$ & $1.325(3)$ & $\mathrm{O} 11-\mathrm{Fe} 1-\mathrm{N} 11$ & $91.10(8)$ & $\mathrm{O} 1-\mathrm{Fe} 1-\mathrm{O} 12$ & $90.39(9)$ \\
$\mathrm{C} 22-\mathrm{O} 22$ & $1.330(3)$ & $\mathrm{O} 12-\mathrm{Fe} 1-\mathrm{O} 22$ & $82.60(8)$ & $\mathrm{O} 1-\mathrm{Fe} 1-\mathrm{O} 22$ & $90.39(7)$ \\
& & $\mathrm{O} 12-\mathrm{Fe} 1-\mathrm{N} 11$ & $95.53(8)$ & $\mathrm{O} 1-\mathrm{Fe} 1-\mathrm{N} 11$ & $87.30(8)$
\end{tabular}

than those reported for the complexes $[\mathrm{Fe}(\mathrm{tcc})(\mathrm{bpia})]\left(\mathrm{ClO}_{4}\right)$ $(2.081 \AA)$ and $[\mathrm{Fe}(\mathrm{tcc})(\mathrm{bpba})]\left(\mathrm{ClO}_{4}\right)\left(\mathrm{CH}_{3}\right)_{2} \mathrm{CO}(2.083 \AA)$, which contain a 1-methylimidazole or benzimidazole group trans to a tetrachlorocatecholato oxygen, respectively..$^{50}$ The Fe1-O11 carboxylato bond length $(1.9516(18) \AA)$ is fairly short, indicating a strong interaction of the carboxylate oxygen with the metal center. This bond length can be compared to the one in [Fe $\mathrm{Fe}^{\mathrm{III}}$ (bpg) (dtbc)] (1.994 $\AA), 52$ in which a carboxylato group is also located trans to a catecholato-oxygen, and the one in $\left[\mathrm{Et}_{4} \mathrm{~N}\right]-$ $\left[\mathrm{Fe}^{\mathrm{III}}(\mathrm{bdmpza}) \mathrm{Cl}_{3}\right](2.049 \AA)$, which contains the tripodal bis(3,5-dimethylpyrazol-2-yl)acetate ligand. ${ }^{30}$ The $\mathrm{C} 12-\mathrm{O} 12$ and $\mathrm{C} 22-\mathrm{O} 22$ bond lengths in the tcc moiety are essentially equal (1.325(3) and 1.330(3) $\AA$, respectively) and are similar to those found in the other $\mathrm{Fe}(\mathrm{IIII})$-tetrachlorocatecholato complexes. . $^{50,53,54}$ Together with the regular $\mathrm{C}-\mathrm{C}$ bond lengths of the aromatic ring, it is clear that the catecholato ligand is bound as an $O, O$ dianion. No evidence for the manifestation of partial semiquinone character of the catecholato ligand is found. However, there is an asymmetry in the binding of the catecholate to the iron center with $\mathrm{Fe}-\mathrm{O}$ bond lengths of 1.9231(18) and 2.0009(18) $\AA\left(\Delta r_{\mathrm{Fe}-\mathrm{O}}=0.078 \AA\right)$. Rather surprising is the observation that the shorter $\mathrm{Fe} 1-\mathrm{O} 12$ bond length is the one trans to the carboxylato ligand, while the longer $\mathrm{Fe} 1-\mathrm{O} 22$ is trans to the

(52) Cox, D. D.; Que, L., Jr. J. Am. Chem. Soc. 1988, 110, 8085-8092.

(53) Merkel, M.; Pascaly, M.; Krebs, B.; Astner, J.; Foxon, S. P.; Schindler, S. Inorg. Chem. 2005, 44, 7582-7589.

(54) Merkel, M.; Schnieders, D.; Baldeau, S. M.; Krebs, B. Eur. J. Inorg. Chem. 2004, 783-790. 


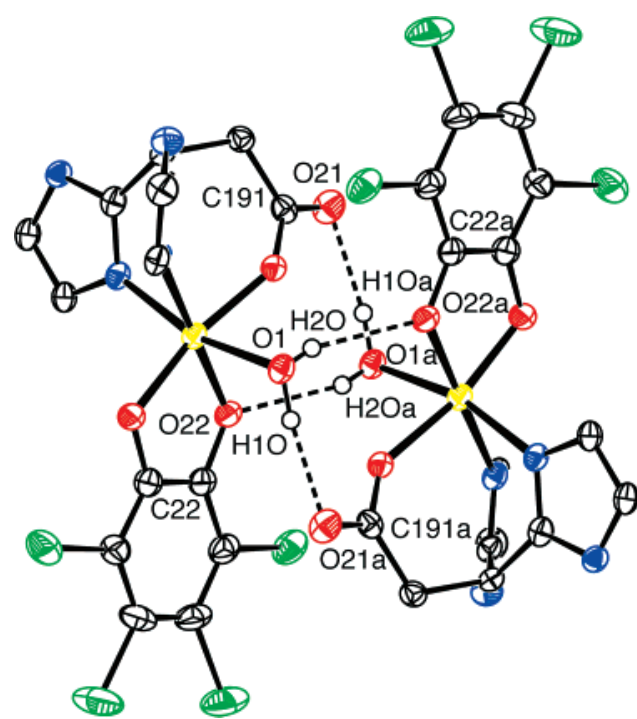

Figure 7. Hydrogen bonding pattern in $\left[\mathrm{Fe}(\mathbf{L 3})(\mathrm{tcc})\left(\mathrm{H}_{2} \mathrm{O}\right)\right](\mathbf{6}) ; \mathrm{C}-\mathrm{H}$ hydrogen atoms and the ethyl and isopropyl groups have been omitted for clarity. Symmetry operation a: $1-x,-y,-z$.

Table 4. Selected Hydrogen Bond Lengths $(\AA)$ and Angles (deg) for $\left[\mathrm{Fe}(\mathbf{L} 3)(\mathrm{tcc})\left(\mathrm{H}_{2} \mathrm{O}\right)\right](\mathbf{6})$; Symmetry Operation a: $1-x,-y,-z$

\begin{tabular}{cccccr}
\hline Donor-H $\cdots$ Acceptor & D-H & H $\cdots$ A & D $\cdots$ A & D-H $\cdots$ A & C-O $\cdots$ H \\
\hline O1-H1O $\cdots$ O21a & $0.92(4)$ & $1.99(4)$ & $2.902(3)$ & $172(3)$ & $97.9(11)$ \\
O1-H2O $\cdots$ O22a & $0.69(4)$ & $2.19(4)$ & $2.843(3)$ & $161(4)$ & $127.6(11)$
\end{tabular}

weaker imidazole nitrogen donor atom. The asymmetric binding of dianionic catecholates to iron has been described before, but in all cases the strongest interaction was found trans to the weakest donor ligand and could therefore be at least partly attributed to a trans influence. ${ }^{19,50,52,55}$ In the complex [ $\mathrm{Fe}^{\mathrm{III}}$ (bpg)(dtbc)] for instance, the asymmetrically chelated dtbc ligand shows a considerably shorter $\mathrm{Fe}-\mathrm{O}_{\text {cat }}$ bond length $(\mathrm{Fe}-$ $\mathrm{O}_{\text {cat }}=1.889 \AA$ ) trans to the weaker tertiary amine donor than the one positioned trans to the carboxylato functionality ( $\mathrm{Fe}-$ $\left.\mathrm{O}_{\text {cat }}=1.989 \AA\right) .{ }^{52}$ In the case of complex 6 , the observed asymmetry in bond lengths seems counterintuitive but can be partly attributed to the involvement of several of the donor atoms in hydrogen bonding interactions. This weakens the donor strength of these trans ligands to the effect that the strength of the $\mathrm{Fe}-\mathrm{O}$ binding becomes inverted. In fact, the water molecule is engaged in two hydrogen bonds, resulting in the formation of dimers of 6 in the solid state (Figure 7, Table 4); hydrogen atom $\mathrm{H} 2 \mathrm{O}$ is intermolecularly bonded to tetrachlorocatechol oxygen $\mathrm{O} 22 \mathrm{a}$, while hydrogen atom $\mathrm{H} 1 \mathrm{O}$ is bonded intermolecularly to the noncoordinated carboxylato oxygen O21a. The unusual $\mathrm{Fe}$-catecholato bond lengths can thus be rationalized by the involvement of both the carbonyl oxygen of the carboxylato group and one of the tetrachlorocatecholate oxygens, $\mathrm{O} 22$, as hydrogen bond acceptors. Interestingly, this asymmetric binding of a catecholato dianion to an $\mathrm{Fe}$ center is also found at the active site of the intradiol cleaving catechol dioxygenases, which require $\mathrm{Fe}(\mathrm{III})$ as a cofactor. Here, the asymmetry is rationalized by trans ligand effects and/or the effect of a highly

(55) Que, L., Jr.; Kolanczyk, R. C.; White, L. S. J. Am. Chem. Soc. 1987, 109, $5373-5380$. conserved hydrogen bonded arginine residue. ${ }^{56,57}$ The longer $\mathrm{Fe}-\mathrm{O}$ bond, which is found trans to a tyrosine residue, is in this case weakened further by the involvement of the same catecholato oxygen in a hydrogen bond with an arginine. Our results show that it is indeed important to take both effects arising from the trans disposition of ligands and the hydrogen bonding interactions into account.

The geometry of $\mathbf{6}$ can best be described as a severely distorted octahedron with the catecholate oxygens (O12 and O22), imidazole N11, and carboxylato O11 occupying the equatorial plane. The Fe1 atom is essentially in the equatorial plane. The axial positions are occupied by imidazole N41 and the water molecule. The strongly deviating transoid $\mathrm{O} 1-\mathrm{Fe} 1-$ N41 angle of $165.65(9)^{\circ}$ is caused by inherent geometrical restrictions imposed by the tripodal ligand and the involvement of the water molecule in two moderately strong hydrogen bonds.

Structural Comparison with the Extradiol Cleaving Enzymes. High-resolution X-ray crystal structures of several of the extradiol cleaving catechol dioxygenases with bound substrate are known. ${ }^{38,58-62}$ Structural data for 2,3-dihydroxybiphenyl 1,2-dioxygenase (BphC) from the Burkholderia cepacia strain LB40061,62 and the Pseudomonas sp. strain KKS102 $2^{58-60}$ with different catechols have for instance been reported. Recently, the structure of the iron-dependent homoprotocatechuate 2,3-dioxygenase (2,3-HPCD) also became available. ${ }^{38}$ The geometry around the iron center of these enzymesubstrate complexes can best be described as square pyramidal, leaving one coordination site open. The iron(II) metal center is coordinated by the three endogenous ligands and a bidentate, asymmetrically bound catecholato ligand. This asymmetry in $\mathrm{Fe}-\mathrm{O}_{\text {cat }}$ distances $(0.2-0.4 \AA)$ is the result of the binding of the substrate as a monoanion. ${ }^{16,61}$ In the structure of $\mathrm{BphC}$ (LB400), ${ }^{61,62}$ an additional water molecule occupies the sixth coordination site, and in this case the geometry can be best described as distorted octahedral with one of the histidine-N and the protonated catechol oxygen donor atoms as the axial ligands. It should be noted, however, that the position of the water molecule is only partly occupied at a relatively long bond length. In Figure 8 the active site structure of BphC (LB400) is compared to the structure of complex $\mathbf{6}$.

From this comparison, complex $\mathbf{6}$ can be regarded as a rather close structural mimic of the enzyme-substrate complex of the extradiol cleaving catechol dioxygenases. For the first time, a mononuclear iron-catecholato complex has been synthesized, which is facially capped by a ligand offering a tridentate $N_{\text {im }}, N_{\text {im }}, O_{\text {carb }}$ donor set. Furthermore, the triangular face of the octahedron built by the facial triad is oriented in the same way as that found in the enzyme; i.e., one of the imidazole groups

(56) Horsman, G. P.; Jirasek, A.; Vaillancourt, F. D.; Barbosa, C. J.; Jarzecki, A. A.; Xu, C.; Mekmouche, Y.; Spiro, T. G.; Lipscomb, J. D.; Blades, M. W.; Turner, R. F. B.; Eltis, L. D. J. Am. Chem. Soc. 2005, 127, 1688216891.

(57) Orville, A. M.; Lipscomb, J. D.; Ohlendorf, D. H. Biochemistry 1997, 36 , 10052-10066.

(58) Sato, M.; Uragami, Y.; Nishizaki, T.; Takahashi, Y.; Sazaki, G.; Sugimoto, K.; Nonaka, T.; Masai, E.; Fukuda, M.; Senda, T. J. Mol. Biol. 2002, 321 $621-636$.

(59) Senda, T.; Sugiyama, K.; Narita, H.; Yamamoto, T.; Kimbura, K.; Fukuda, M.; Sato, M.; Yano, K.; Mitsui, Y. J. Mol. Biol. 1996, 255, 735-752.

(60) Uragami, Y.; Senda, T.; Sugimoto, K.; Sato, N.; Nagarajan, V.; Masai, E.; Fukuda, M.; Mitsui, Y. J. Inorg. Biochem. 2001, 83, 269-279.

(61) Vaillancourt, F. H.; Barbosa, C. J.; Spiro, T. G.; Bolin, J. T.; Blades, M. W.; Turner, R. F. B.; Eltis, L. D. J. Am. Chem. Soc. 2002, 124, 24852496.

(62) Vaillancourt, F. H.; Han, S.; Fortin, P. D.; Bolin, J. T.; Eltis, L. D. J. Biol. Chem. 1998, 273, 34887-34895. 


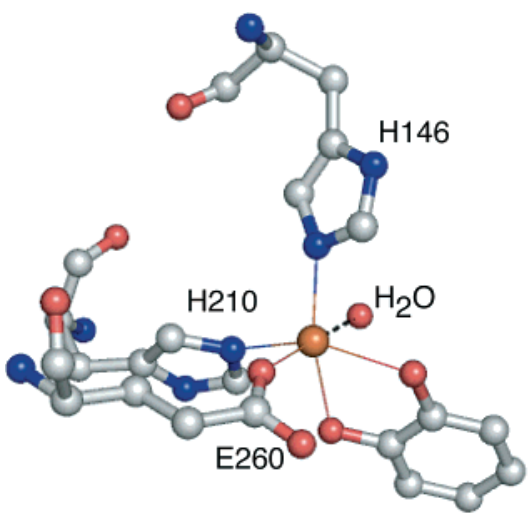

BphC

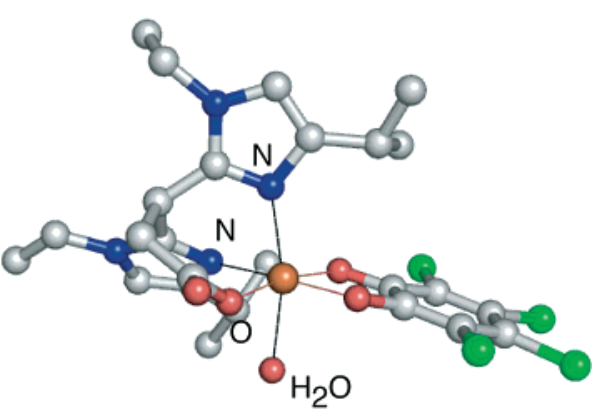

6

Figure 8. First coordination sphere of the iron(II) metal center of the 2,3-dihydroxybiphenyl 1,2 dioxygenase E-S complex ${ }^{61,62}$ (1 KND.pdb) (left) and that of complex $\left[\mathrm{Fe}(\mathbf{L 3})(\mathrm{tcc})\left(\mathrm{H}_{2} \mathrm{O}\right)\right]$ (6) (right). (Picture generated with PyMOL. ${ }^{63}$ )

occupies an axial position. The relative orientation of the catechol is, however, different. In the enzyme, both catechol oxygens are positioned trans to a histidine $N$ donor atom, and as a result, the vacant site (or coordinated water molecule) in the octahedron is located in the equatorial plane, trans to the carboxylato $O$ donor. In model complex $\mathbf{6}$, the positions of the water and one of the catechol oxygens are interchanged, and now the sixth available coordination site is found at the axial position trans to one of the imidazole $N$ donor atoms. Interestingly, the trans-disposition of the vacant site has been invoked as a possible decisive factor in the regioselectivity of the oxidative catechol cleavage. ${ }^{38}$ In addition, the coordinated water molecule nicely illustrates the availability of the vacant coordination site in 6. Although the complex is constructed with the sterically most demanding ligand $\mathbf{L} \mathbf{3}$, the metal center is still accessible and the vacant site can be occupied either by a solvent molecule, as in the enzyme resting state, or by dioxygen during catalytic turnover (vide infra). The model complex is imperfect in the sense that it contains an $\mathrm{Fe}(\mathrm{III})$ metal center. The higher oxidation state of the metal is reflected in the overall shorter bond lengths when compared to the enzyme crystal structures. The enzyme furthermore provides the $N, N, O$ donor set with more flexible $\mathrm{X}-\mathrm{Fe}-\mathrm{Y}$ angles because the donor groups are part of the larger enzyme backbone, whereas in $\mathbf{6}$ the angles are fixed by the ring strain of the three fused 6,7,7membered chelate rings.

Dioxygen Reactivity. In order to determine whether these new iron-catecholato complexes exhibit extradiol catechol cleaving activity, we studied the dtbc complexes for their dioxygen reactivity. ${ }^{64}$ The same observations were made for the complexes from all three ligands. Yellow-brown solutions of the $\left[\mathrm{Fe}^{\mathrm{II}}(\mathbf{L})(\mathrm{Hdtbc})\right]$ complexes all converted within seconds to intensely colored blue-purple solutions upon exposure to air at ambient temperature. This fast and drastic color change was monitored by UV-vis absorption spectroscopy. New bands emerged at around 324, 490, and $800 \mathrm{~nm}$ (Figure 9), which are identical to those of the independently synthesized $\left[\mathrm{Fe}^{\mathrm{III}}(\mathbf{L})\right.$ (dtbc)] complexes. The latter two bands can be assigned to catecholato-to-iron(III) charge-transfer transitions. ${ }^{49}$ Of the few characterized mononuclear iron(II) - catecholato complexes, the

(63) Delano, W. L. The PyMOL Molecular Graphics System; Delano Scientific: San Carlos, CA, U.S.A., 2002

(64) Initial experiments with ferrous and ferric complexes of the ligand with pyrocatechol did not show any oxidative cleavage at an appreciable rate.

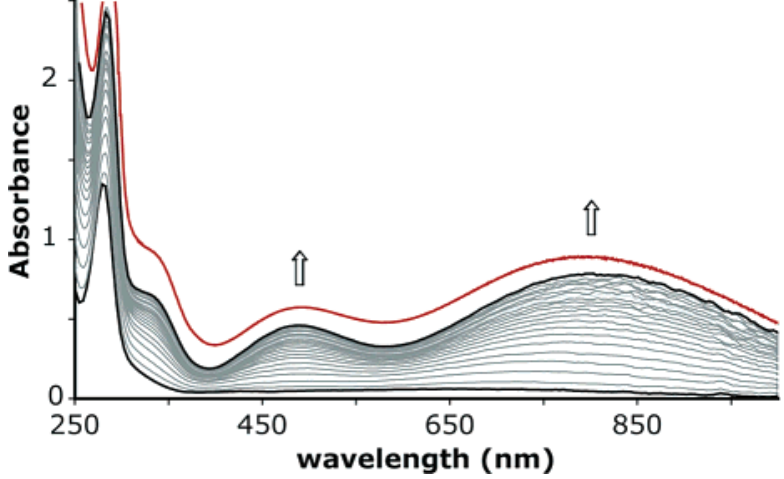

Figure 9. UV-vis spectral changes upon exposure of $\left[\mathrm{Fe}^{\mathrm{II}}(\mathbf{L} \mathbf{1})(\mathrm{Hdtbc})\right]$ in methanol to air, showing the formation of $\left[\mathrm{Fe}^{\mathrm{III}}(\mathbf{L} \mathbf{1})(\mathrm{dtbc})\right]$. A spectrum was recorded every $6 \mathrm{~s}$. The UV-vis spectrum of anaerobically synthesized $\left[\mathrm{Fe}^{\mathrm{III}}(\mathbf{L} \mathbf{1})(\mathrm{dtbc})\right]$ is included as the top line. Arrows indicate the increase in absorption over time.

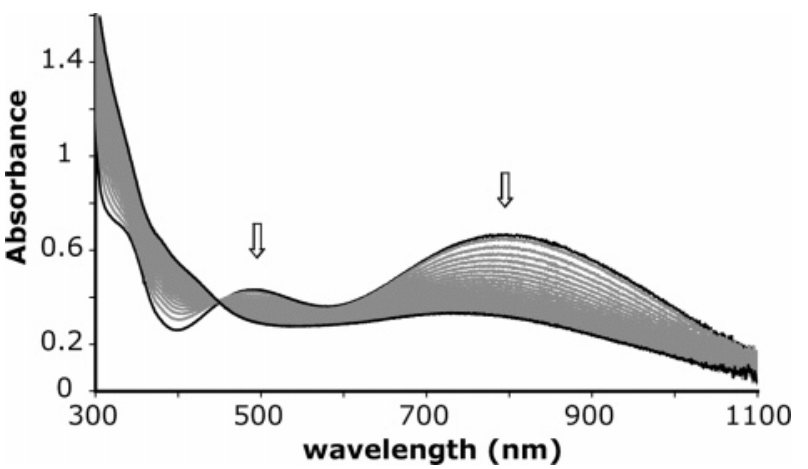

Figure 10. UV-vis spectral changes upon exposure of anaerobically synthesized $\left[\mathrm{Fe}^{\mathrm{III}}(\mathbf{L} \mathbf{1})(\mathrm{dtbc})\right]$ in methanol to ambient conditions. A spectrum was recorded every $20 \mathrm{~min}$. Arrows indicate the decrease in absorption over time.

systems of Que et al. and Moro-oka et al. showed the same rapid $\mathrm{Fe}^{\mathrm{II}}$-to- $-\mathrm{Fe}^{\mathrm{III}}$ - catecholato oxidation reaction with $\mathrm{O}_{2}{ }^{16,19,28}$ In the $\mathrm{FeCl}_{2} / \mathrm{tacn} / \mathrm{cat}$ system reported by Bugg et al. only slow conversion to an iron(III) species has been observed. In their system the actual catechol cleavage step mediated by an Fe(II) species is the faster reaction. ${ }^{23,65}$

The initial very fast formation of the blue-purple $\left[\mathrm{Fe}^{\mathrm{III}}(\mathbf{L})\right.$ (dtbc)] species is followed by a second, much slower color change; i.e., the intense blue-purple color fades and a green

(65) Lin, G.; Reid, G.; Bugg, T. D. H. Chem. Commun. 2000, 1119-1120. 
Table 5. Organic Products Obtained upon Reaction of Complexes $[\mathrm{Fe}(\mathrm{L})(\mathrm{dtbc})]$ with $\mathrm{O}_{2}{ }^{a}$

\begin{tabular}{|c|c|c|c|c|c|c|c|}
\hline complex & additive & solvent & $\operatorname{conv}(\%)$ & extradiol $^{b}(\%)$ & intradiol (\%) & quinone (\%) & ref \\
\hline$[\mathrm{Fe}(\mathbf{L 1})(\mathrm{dtbc})]$ & & $\mathrm{CH}_{2} \mathrm{Cl}_{2}$ & 92 & $30(69 / 31)$ & 27 & 43 & \\
\hline$[\mathrm{Fe}(\mathbf{L} 2)(\mathrm{dtbc})]$ & & $\mathrm{CH}_{2} \mathrm{Cl}_{2}$ & 90 & $27(64 / 36)$ & 29 & 44 & \\
\hline$[\mathrm{Fe}(\mathbf{L 3})(\mathrm{dtbc})]$ & & $\mathrm{CH}_{2} \mathrm{Cl}_{2}$ & 93 & $18(42 / 58)$ & 22 & 60 & \\
\hline$[\mathrm{Fe}(\mathbf{L} 2)(\mathrm{dtbc})]$ & pyridine ( 20 equiv) & $\mathrm{CH}_{2} \mathrm{Cl}_{2}$ & 100 & $21(69 / 31)$ & 20 & 59 & \\
\hline$[\mathrm{Fe}(\mathbf{L} 2)(\mathrm{dtbc})]$ & {$\left[\mathrm{Et}_{3} \mathrm{NH}\right] \mathrm{BF}_{4}$ ( 1 equiv) } & $\mathrm{CH}_{2} \mathrm{Cl}_{2}$ & 83 & $38(63 / 37)$ & 21 & 41 & \\
\hline$[\mathrm{Fe}(\mathbf{L} 2)(\mathrm{dtbc})]$ & & $\mathrm{CH}_{3} \mathrm{CN}$ & 100 & -- & -- & 100 & \\
\hline$[\mathrm{Fe}(\mathbf{L 2})(\mathrm{dtbc})]$ & & $\mathrm{CH}_{3} \mathrm{OH}$ & 100 & -- & 11 & 89 & \\
\hline$[\mathrm{FeCl}(\mathrm{dtbc})(\operatorname{tacn})]$ & & $\mathrm{CH}_{2} \mathrm{Cl}_{2}$ & & 3 & -- & 82 & 22 \\
\hline$[\mathrm{FeCl}(\mathrm{dtbc})(\mathrm{tacn})]$ & & $\mathrm{CH}_{3} \mathrm{CN}$ & & 35 & -- & 65 & 41 \\
\hline$\left[\mathrm{FeCl}(\mathrm{dtbc})\left(\mathrm{Me}_{3}-\mathrm{tacn}\right)\right]$ & $\operatorname{AgOTf}(1 \mathrm{eq})$ & $\mathrm{CH}_{2} \mathrm{Cl}_{2}$ & & 98 & -- & -- & 43 \\
\hline$[\mathrm{FeCl}(\mathrm{dtbc})($ terpy $)]$ & & $\mathrm{CH}_{2} \mathrm{Cl}_{2}$ & & -- & 20 & 78 & 43 \\
\hline$\left[\mathrm{Fe}(\mathrm{dtbc})\left(\mathrm{Tp}^{i \mathrm{Pr} 2}\right)\right]$ & & toluene & & 67 & 33 & -- & 28 \\
\hline
\end{tabular}

${ }^{a}$ Selected dtbc cleavage data from related iron complexes with tridentate ligands has been included for comparison. ${ }^{b}$ Ratio in parentheses: (4,6-di-tertbutyl-2-pyrone/3,5-di-tert-butyl-2-pyrone).

Scheme 1

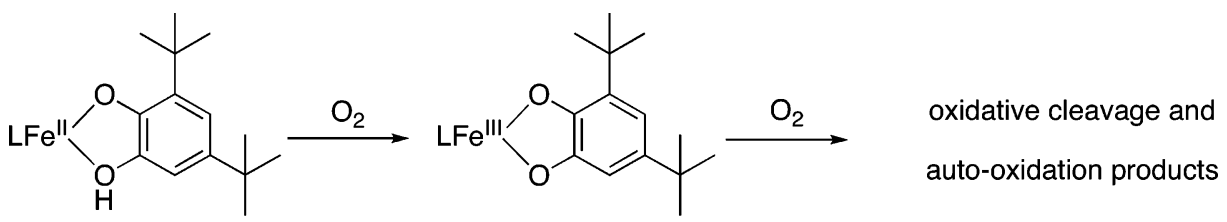

Observed Products:

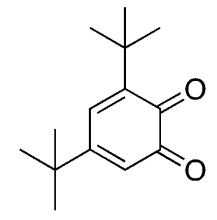

Auto-oxidation

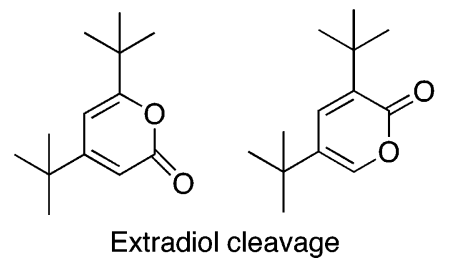

Extradiol cleavage

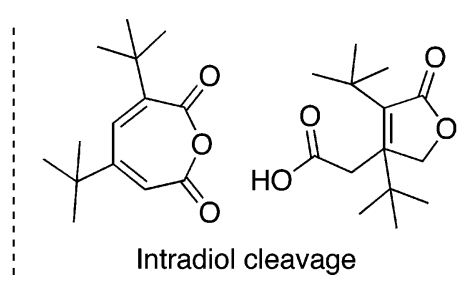

Intradiol cleavage solution is obtained. The rate of disappearance of the characteristic catecholato-iron(III) LMCT bands in the UV-vis absorption spectra (Figure 10) depends strongly on the nature of the solvent and takes from a few hours in polar solvents (e.g., methanol) up to several days in more apolar solvents (e.g., dichloromethane).

The anaerobically synthesized and isolated $\left[\mathrm{Fe}^{\mathrm{III}}(\mathbf{L})(\mathrm{dtbc})\right]$ complexes showed identical behavior upon exposure to air as the in situ formed $\left[\mathrm{Fe}^{\mathrm{III}}(\mathbf{L})(\mathrm{dtbc})\right]$ complexes did. Therefore, further experiments were carried out with independently synthesized and isolated $\mathrm{Fe}^{\mathrm{III}}$ complexes. In order to establish the identity of the products as well as the regioselectivity of the reaction, the products were isolated from the reaction mixture, characterized by ${ }^{1} \mathrm{H}$ NMR spectroscopy and GC-MS and compared to authentic samples. ${ }^{43,66}$ The product distribution was found to be very solvent dependent (Table 5). When the reactions were performed in a strongly coordinating solvent like acetonitrile, full conversion to the auto-oxidation product 3,5di-tert-butylbenzoquinone was observed (Scheme 1). Changing the solvent to methanol resulted in the formation of some of the intradiol cleavage product 3,5-di-tert-butyl-5-carboxymethyl2-furanone methyl ester (around 10\%), in addition to the quinone which was obtained in $90 \%$ yield. Since the availability of a vacant site has been argued to be an essential factor for the occurrence of extradiol type catechol cleavage, ${ }^{3,43}$ we also studied the oxygenation in noncoordinating solvents. Indeed, when dichloromethane was employed as the solvent, the product

(66) Demmin, T. R.; Rogic, M. M. J. Org. Chem. 1980, 45, 1153-1156. distribution changed completely. Although still about $45 \%$ of the 3,5-di-tert-butylcatechol was converted into the quinone, a considerable amount of the extradiol type cleavage products 4,6di-tert-butyl-2-pyrone and 3,5-di-tert-butyl-2-pyrone was now formed in about $30 \%$. Interestingly, intradiol type products were again observed in the product mixture, accounting for the remaining $30 \%$ of organic products and providing a mass balance in product formation. Similar results were obtained for the reaction of all three $[\mathrm{Fe}(\mathbf{L})(\mathrm{dtbc})]$ complexes, and in each case an extradiol/intradiol molar ratio close to 1 was observed. Reactions of complex $[\mathrm{Fe}(\mathbf{L 3})(\mathrm{dtbc})]$ in dichloromethane showed a lower yield of ring cleavage products, which probably reflects the more limited accessibility of the vacant site due to the use of a more sterically demanding ligand. This is the first time that extradiol type cleavage has been observed with a mixed donor set $(N, N, O)$ ligand. Que et al. showed that for [Fe(dtbc)$(\operatorname{tacn})]^{+}$the formation of the quinone auto-oxidation product, originally accounting for $82 \%$, could be completely surpressed by the addition of 20 equiv of an additional Lewis base, such as pyridine. ${ }^{22}$ For our system the addition of pyridine (20 equiv) to the complex in dichloromethane did markedly increase the reaction rate but ultimately resulted in an increase in the amount of quinone product formed (59\% vs 44\%). On the other hand, the addition of a proton donor, such as $\left[\mathrm{Et}_{3} \mathrm{NH}\right] \mathrm{BF}_{4}$, resulted in a significant increase in the selectivity toward extradiol cleavage. Almost twice as much of the extradiol products than intradiol products are obtained now. The dioxygen reactivity of the ironcatecholato complexes is summarized in Scheme 1. 


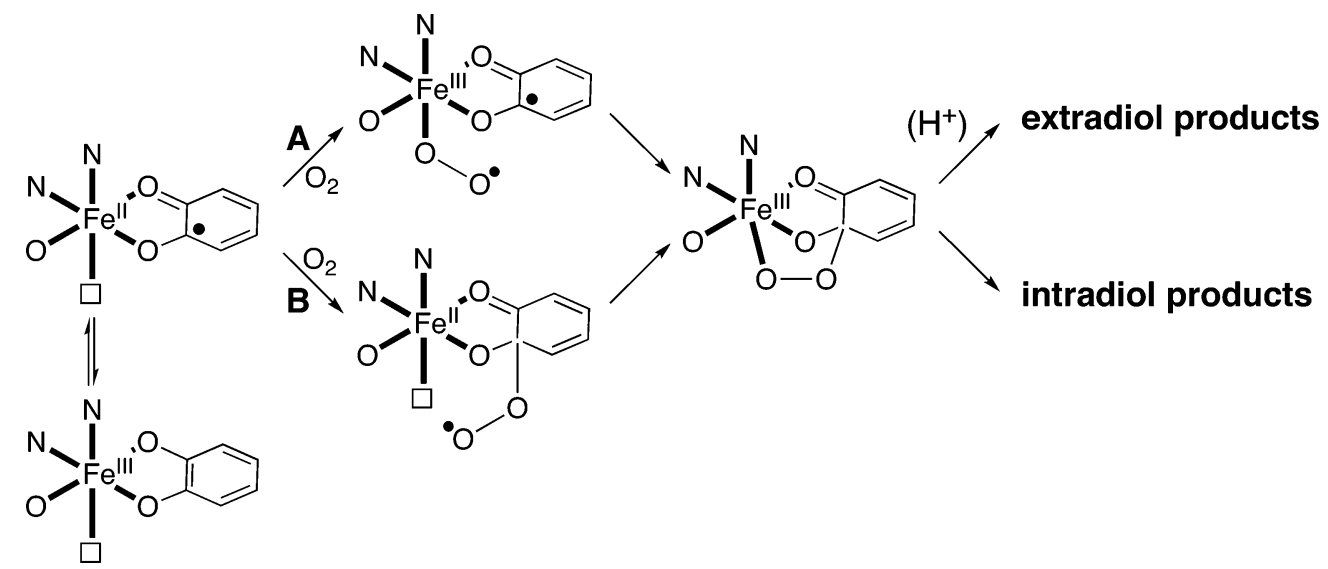

Figure 11. Proposed oxidative cleavage mechanism.

\section{Discussion}

Crystallographic data on a wide variety of enzymes have firmly established the 2-His-1-carboxylate facial triad as one of Nature's recurring structural motifs. ${ }^{1,7}$ In this paper, we have presented accurate structural models of this facial triad. The ligand family of (substituted) bis(1-alkylimidazol-2-yl)propionates provides the metal center with a tripodal, tridentate monoanionic framework and incorporates the biologically relevant imidazole $N$ and carboxylate $O$ donor atoms. The crystal structure of $\left[\mathrm{Fe}(\mathbf{L 3})(\mathrm{tcc})\left(\mathrm{H}_{2} \mathrm{O}\right)\right](\mathbf{6})$ nicely illustrates the facial capping of the ligand and shows their general potential as models for the 2-His-1-carboxylate facial triad enzyme superfamily. The iron-catecholato complexes containing these ligands are initially isolated as coordinatively unsaturated, five-coordinate iron complexes. The monoanionic nature of the $N, N, O$ ligand, together with the binding of the substrate, excludes the need for further ligands to obtain charge neutrality. The complexes therefore have a specifically designed vacant site available for the coordination of a solvent molecule, additional donor groups (e.g., pyridine) or dioxygen. The necessity of this vacant site for the desired reactivity is clearly illustrated by the observed solvent dependency of the oxidative chemistry of the $[\mathrm{Fe}(\mathbf{L})$ (dtbc)] complexes.

Regarding the displayed reactivity, several points should be considered. First of all, the initial rapid oxidation of the ferrous complex to the ferric complex seems to be an inherent property of the few ferrous active site analogues reported so far and can probably be attributed to insufficient site isolation provided by the model ligand set. The resulting iron(III)-catecholato complexes are, however, still reactive toward dioxygen, and oxidative catechol cleavage products are obtained when the reactions are performed in noncoordinating solvents. The formation of extradiol cleavage products upon oxygenation of the dtbc complexes shows their combined structural and functional modeling potential. Actually, these complexes are the first $N, N, O$ mixed-donor complexes that display extradiol type catechol cleavage. Interestingly, we observe both extradiol and intradiol type catechol cleavage in comparable amounts. The few complexes reported thus far that are able to elicit extradiol cleavage also mediate concomitant intradiol cleavage, at least to some extent. The only synthetic complex that exclusively affords extradiol products is $\left[\mathrm{Fe}(\mathrm{Cl})(\mathrm{dtbc})\left(\mathrm{Me}_{3}-\right.\right.$ tacn)], which required 1 equiv of $\mathrm{AgBF}_{4}$ to generate an empty coordination site. ${ }^{43}$ This system seems to be quite exceptional, as in most cases both product types are found. This suggests quite similar mechanisms for the two reactions and points at subtle influences on the ultimate product selectivity.

Several mechanisms have been proposed to account for the observed selectivity of the different catechol cleaving enzymes. In all cases, the mechanisms converge on a similar proximal alkylperoxo species, which is implicated as the productive intermediate (Figure 11). Starting from this common intermediate different explanations have been offered to explain how the enzymes catalyze the regiospecific ring cleavage. Bugg et al. argued that stereoelectronic factors determine the fate of the alkylperoxo species. ${ }^{2,3}$ (Pseudo)-axial orientation of the peroxide with respect to the cyclohexadiene ring would lead to alkenyl migration and extradiol type cleavage, whereas a (pseudo)equatorial orientation would lead to an acyl migration resulting in intradiol type cleavage. These different orientations could be the consequence of the different ligation number of the metals in the intra- and extradiol dioxygenases. The fourfold coordination $\left(\mathrm{His}_{2} \mathrm{Tyr}_{2}\right)$ in the intradiol dioxygenases could, in this view, only lead to a (pseudo)-equatorial orientation, whereas the threefold coordination ( $\mathrm{His}_{2} \mathrm{Glu}$ ) in the extradiol dioxygenases results in an axial vacant site and subsequent (pseudo)-axial orientation. However, crystal structural data on protocatechuate 3,4-dioxygenase, an intradiol cleaving enzyme, shows that upon catechol binding the axial tyrosine residue dissociates from the metal center. ${ }^{57}$ Therefore, in both enzymes an $N, N, O$ ligated metal center with an axially oriented alkylperoxo intermediate can be implicated. This geometrical situation is very similar to the model complexes presented in this study. The facial capping of the $N, N, O$ ligand ensures that the vacant site is always oriented axially relative to the catechol plane and the overall geometry is therefore most suited for the formation of a pseudoaxial peroxo intermediate. There are two possible routes to this intermediate. As indicated by the spectroscopic data, the catecholato-to-Fe(III) charge-transfer transitions confer some iron(II)-semiquinonato character on the complexes. ${ }^{43}$ The available vacant site now allows direct attack of the metal center by dioxygen and subsequent attack of the semiquinone by a superoxide species (Figure 11A) or the direct attack of the substrate by dioxygen and recombination with the metal center (Figure 11B). Both pathways would lead to the same intermediate. It has been argued that second-sphere active-site residues may participate in catalysis and that they are one of the decisive 
factors for regiospecific cleavage. ${ }^{37,38,67-69}$ A recent DFT study proposed that the actual selectivity is determined by the character of the products of the $\mathrm{O}-\mathrm{O}$ cleavage of the alkylperoxo intermediate. ${ }^{37}$ These calculations showed that two transition states could be found upon cleavage of the alkylperoxide intermediate, the one leading to extradiol type cleavage being the one with the lowest barrier. A critical parameter in the calculation was the inclusion of a (fully conserved) second sphere protonated histidine residue. Without this proton donor, the intradiol cleavage pathway became the one with the lowest energy barrier. Recent experiments by Groce and Lipscomb support the suggested critical role of the conserved histidine, since a mutation of this residue to a phenylalanine in homoprotocatechuate 2,3-dioxygenase changed its product selectivity from extradiol to intradiol cleavage ${ }^{67}$ An increase in extradiol type cleavage by the addition of a proton donor was also found in one biomimetic study. ${ }^{23}$ The similar yields for the extra- and intradiol type products suggest that our complexes are not selective for one of the two competing pathways, resulting in a nonselective cleavage of the $\mathrm{O}-\mathrm{O}$ bond. The addition of a proton donor to the reaction mixture did result in an increase of extradiol type cleavage, supporting the hypothesis that the presence of a proton donor enhances extradiol type cleavage.

We have shown that the bis(1-alkylimidazol-2-yl)propionates accurately model the first coordination sphere of the 2-His-1carboxylate facial triad and that a ferric ion ligated by this triad is capable of both intra- and extradiol type cleavage of 3,5-ditert-butylcatechol. Previous studies showed that intradiol cleaving enzymes can be turned into extradiol ones while retaining the ferric oxidation state ${ }^{70}$ and that extradiol cleaving enzymes can display intradiol type cleavage by site-directed modification, which illustrates the ability of a ferrous ion ligated by the 2-His1-carboxylate facial triad to mediate both reactivities. ${ }^{67}$ All together this demonstrates that neither the metal valency nor the exact ligand donor set are the decisive factors for regioselectivity. The selectivity of ring cleavage seems to be determined by the acid-base chemistry of conserved second sphere residues that interact with an isostructural Fe-peroxo catecholato complex.

\section{Summary and Perspective}

As part of our efforts to model the 2-His-1-carboxylate facial triad, we have studied the iron coordination chemistry of the new family of the substituted 3,3-bis(1-alkylimidazol-2-yl)propionate ligands. The synthesized iron-catecholato complexes demonstrate the general potential of these ligands to mimic this facial triad. Mononuclear iron complexes were obtained that are facially capped by an $N, N, O$ ligand including the biologically relevant imidazole and carboxylate donor groups. The complexes provide good models for the enzyme-substrate complex of the extradiol cleaving catechol dioxygenases and provide more insight into the factors governing the reactivity of these enzymes. Similar five-coordinate metal-cofactor/substrate complexes are also found in the biggest subgroup of the enzyme superfamily, the $\alpha$-ketoglutarate dependent enzymes, and are, therefore, quite

(67) Groce, S. L.; Lipscomb, J. D. J. Am. Chem. Soc. 2003, 125, 11780-11781. (68) Groce, S. L.; Lipscomb, J. D. Biochemistry 2005, 44, 7175-7188.

(69) Mendel, S.; Arndt, A.; Bugg, T. D. H. Biochemistry 2004, 43, 1339013396.

(70) Fujiwara, M.; Golovleva, L. A.; Saeki, Y.; Nozaki, M.; Hayaishi, O. J. Biol. Chem. 1975, 250, 4848-4855. characteristic for the activated enzyme structures. Further efforts can now be extended to the modeling of other members of the 2-His-1-carboxylate enzyme superfamily and the applicability of iron complexes of these ligands as new catalysts for oxidative transformations in organic synthesis. These studies are currently under way in our laboratory.

\section{Experimental Section}

Air-sensitive organic reactions were carried out under an atmosphere of dry, oxygen-free $\mathrm{N}_{2}$ using standard Schlenk techniques. THF was dried over sodium benzophenone ketyl and distilled under $\mathrm{N}_{2}$ prior to use. Methanol was dried over magnesium methoxide and distilled under $\mathrm{N}_{2}$ prior to use. All iron complexes were synthesized and handled under an argon atmosphere using standard Schlenk techniques. Solvents were thoroughly deoxygenated with argon before use. ${ }^{1} \mathrm{H}$ and ${ }^{13} \mathrm{C}\left\{{ }^{1} \mathrm{H}\right\}$ NMR spectra were recorded on Varian AS400 and Varian Inova 300 spectrometers, operating at $25^{\circ} \mathrm{C}$. Elemental microanalyses were carried out by the Microanalytisches Laboratorium Dornis \& Kolbe, Mulheim a.d. Ruhr, Germany. ESI-MS spectra were recorded on a Micromass LC-TOF mass spectrometer by the department of Biomolecular Mass Spectrometry, Utrecht University. Electrospray mass spectra under anaerobic conditions were recorded at the University of Groningen on an API 3+ triple quadrupole mass spectrometer (Sciex, Concord, Ontario, Canada) equipped with a modified pneumatically assisted electrospray (IonSpray) interface. ${ }^{71}$ The homemade frontcover and IonSpray interface ensure a gastight ion source. The atmospheric pressure ion source was first evacuated and then filled with dry nitrogen. Nitrogen was used as the nebulizing gas and curtain gas. Sample preparation took place in a nitrogen-filled glove box. The syringe pump used for sample introduction was also placed inside the glove box, and a $1.6 \mathrm{~mm}$ o.d. $0.3 \mathrm{~mm}$ i.d. Teflon tube was connected between the syringe pump and the IonSpray interface. Mass spectra were recorded as Q1 scans with a step size of 0.1 and a dwell time of $1 \mathrm{~ms}$. EPR spectra were recorded on a Bruker ER 200 D spectrometer with an ER $4116 \mathrm{DM}$ resonator and a home-built helium flow cooling system. UVvis spectra were recorded on a Cary 50 Varian spectrometer equipped with a Helma emersion probe for air-sensitive experiments. Solution magnetic moments were determined by the Evans' NMR method in acetone- $d_{6} /$ cyclohexane $(95 / 5 \mathrm{v} / \mathrm{v})$ at $25^{\circ} \mathrm{C} .{ }^{46,47}$ The ligands K[L1] (14) and $\mathrm{K}[\mathbf{L 2}]$ (15) were prepared according to a previously published procedure. ${ }^{33}$ Tetrachlorocatechol was recrystallized from anhydrous toluene before use. $\mathrm{Fe}(\mathrm{OTf})_{2} \cdot 2 \mathrm{MeCN}$ was synthesized according to a literature procedure. ${ }^{72}$ All other chemicals were commercially obtained and used as received.

[Fe $\left.\mathrm{F}^{\mathrm{II}}(\mathbf{L 1})(\mathbf{H t c c})\right]$ (1): To a solution of K[L1] (14) (175 mg, 0.64 $\mathrm{mmol})$ in hot methanol $(10 \mathrm{~mL})$ was added a colorless solution of $\mathrm{Fe}$ $(\mathrm{OTf})_{2} \cdot 2 \mathrm{MeCN}(279 \mathrm{mg}, 0.64 \mathrm{mmol})$ in methanol $(10 \mathrm{~mL})$ upon which the solution turned slightly yellow. The solution was then stirred for $30 \mathrm{~min}$ at $50{ }^{\circ} \mathrm{C}$. A solution of $\mathrm{H}_{2} \mathrm{tcc}(159 \mathrm{mg}, 0.79 \mathrm{mmol})$ and 1.1 equiv of $\mathrm{Et}_{3} \mathrm{~N}(100 \mu \mathrm{L})$ in methanol $(8 \mathrm{~mL})$ was added to the hot reaction mixture, and immediately a color change to very deep purple was observed. The reaction mixture was then stirred for $10 \mathrm{~min}$ at an elevated temperature, and gradually a purple precipitate formed. The solution was concentrated in vacuo, and the solid purple residue was washed with demineralized water $(2 \times 20 \mathrm{~mL})$ and dried in vacuo to yield a purple powder $(206 \mathrm{mg}, 60 \%)$. Anal. Calcd for $\mathrm{C}_{17} \mathrm{H}_{14} \mathrm{Cl}_{4} \mathrm{FeN}_{4} \mathrm{O}_{4}$ (535.97): C, 38.10; H, 2.63; N, 10.45. Found: C, 37.87; H, 2.60; N, 10.29. UV-vis (methanol, $\epsilon\left[\mathrm{M}^{-1} \mathrm{~cm}^{-1}\right]$ ): $\lambda_{\max }=597$ (3300) nm. ESIMS: $m / z=535.96\left\{[\mathrm{M}]^{+}\right.$, calcd 535.91 $\}$. Solution magnetic moment (Evans' method): $\mu_{\mathrm{eff}}=5.2 \mu_{\mathrm{B}}$.

[Fe $\left.{ }^{\mathrm{II}}(\mathbf{L 2})(\mathbf{H t c c})\right]$ (2). To a solution of K[L2] (15) (138 mg, 0.37 $\mathrm{mmol})$ in hot methanol $(10 \mathrm{~mL})$ was added a colorless solution of $\mathrm{Fe}$ -

(71) Bruins, A. P.; Covey, T. R.; Henion, J. D. Anal. Chem. 1987, 59, 26422646.

(72) Hagen, K. S. Inorg. Chem. 2000, 39, 5867-5869. 
$(\mathrm{OTf})_{2} \cdot 2 \mathrm{MeCN}(161 \mathrm{mg}, 0.37 \mathrm{mmol})$ in methanol $(10 \mathrm{~mL})$ upon which the solution turned yellow. The solution was then stirred for $30 \mathrm{~min}$ at $50{ }^{\circ} \mathrm{C}$. A solution of $\mathrm{H}_{2} \mathrm{tcc}(92 \mathrm{mg}, 0.37 \mathrm{mmol})$ and 1.1 equiv of $\mathrm{Et}_{3} \mathrm{~N}$ $(57 \mu \mathrm{L})$ in methanol $(8 \mathrm{~mL})$ was added to the hot reaction mixture, and immediately a color change to very deep purple was observed. The reaction mixture was then stirred for $10 \mathrm{~min}$ at an elevated temperature, and gradually a purple precipitate formed. The solution was concentrated in vacuo, and the solid purple residue was washed with demineralized water $(3 \times 20 \mathrm{~mL})$ and dried in vacuo to yield a purple powder (101 mg, 39\%). Anal. Calcd for $\mathrm{C}_{25} \mathrm{H}_{18} \mathrm{Cl}_{4} \mathrm{FeN}_{4} \mathrm{O}_{4}$ (636.09): C, 47.21; H, 2.85; N, 8.81. Found: C, 47.02; H, 2.74; N, 8.64. UV-vis (methanol, $\epsilon\left[\mathrm{M}^{-1} \mathrm{~cm}^{-1}\right]$ ): $\lambda_{\max }=603(2400) \mathrm{nm}$. ESIMS: $m / z=636.13\left\{[\mathrm{M}]^{+}\right.$, calcd 635.94$\}, 658.14\left\{[\mathrm{M}-\mathrm{H}+\mathrm{Na}]^{+}\right.$, calcd 657.92\}, $674.07\left\{[\mathrm{M}-\mathrm{H}+\mathrm{K}]^{+}\right.$, calcd 673.90\}. Solution magnetic moment (Evans' method): $\mu_{\text {eff }}=5.3 \mu_{\mathrm{B}}$.

[Fe $\left.\mathrm{F}^{\mathrm{II}}(\mathbf{L 3})(\mathbf{H t c c})\right](3)$. To a colorless solution of K[L3] (13) $(88 \mathrm{mg}$, $0.23 \mathrm{mmol})$ in hot methanol $(10 \mathrm{~mL})$ was added a colorless solution of $\mathrm{Fe}(\mathrm{OTf})_{2} \cdot 2 \mathrm{MeCN}(100 \mathrm{mg}, 0.23 \mathrm{mmol})$ in methanol $(10 \mathrm{~mL})$ upon which the solution turned yellow. The solution was then stirred for 30 min at $50{ }^{\circ} \mathrm{C}$. A solution of $\mathrm{H}_{2} \mathrm{tcc}(56 \mathrm{mg}, 0.23 \mathrm{mmol})$ and 1.1 equiv of $\mathrm{Et}_{3} \mathrm{~N}(35 \mu \mathrm{L})$ in methanol $(8 \mathrm{~mL})$ was added to the hot reaction mixture, and immediately a color change to very deep burgundy red was observed. The clear reaction mixture was then stirred for $10 \mathrm{~min}$ at elevated temperature, cooled to room temperature, and concentrated in vacuo. The solid purple-red residue was washed with demineralized water $(2 \times 20 \mathrm{~mL})$ and dried under reduced pressure to yield a purplered powder (107 mg, 72\%). Anal. Calcd for $\mathrm{C}_{25} \mathrm{H}_{30} \mathrm{Cl}_{4} \mathrm{FeN}_{4} \mathrm{O}_{4}$ (648.19): C, 46.32; H, 4.67; N, 8.64. Found: C, 46.18; H, 4.57; N, 8.48. UV-vis (methanol, $\epsilon\left[\mathrm{M}^{-1} \mathrm{~cm}^{-1}\right]$ ): $\lambda_{\max }=606(5000) \mathrm{nm}$. ESIMS: $m / z=347.34\left\{[\mathrm{~L}+2 \mathrm{H}]^{+}\right.$, calcd 347.17$\}, 648.24\left\{[\mathrm{M}]^{+}\right.$, calcd $648.03\}, 670.25\left\{[\mathrm{M}-\mathrm{H}+\mathrm{Na}]^{+}\right.$, calcd 670.02\}. Solution magnetic moment (Evans' method): $\mu_{\text {eff }}=5.2 \mu_{\mathrm{B}}$.

[Fe $\left.\mathrm{Fe}^{\mathrm{III}}(\mathbf{L 1})(\mathrm{tcc})\right]$ (4). To a solution of K[L1] (14) $(128 \mathrm{mg}, 0.47 \mathrm{mmol})$ in hot methanol $(10 \mathrm{~mL})$ was added an orange solution of $\mathrm{Fe}\left(\mathrm{NO}_{3}\right)_{3}$. $9 \mathrm{H}_{2} \mathrm{O}(190 \mathrm{mg}, 0.47 \mathrm{mmol})$ in methanol $(10 \mathrm{~mL})$, and immediately a color change to red-brown was observed. This solution was stirred for $10 \mathrm{~min}$ at $50{ }^{\circ} \mathrm{C}$. A solution of $\mathrm{H}_{2} \mathrm{tcc}(117 \mathrm{mg}, 0.47 \mathrm{mmol})$ and 2.5 equiv of $\mathrm{Et}_{3} \mathrm{~N}(170 \mu \mathrm{L})$ in methanol $(8 \mathrm{~mL})$ was added to the hot reaction mixture, and immediately the color of the solution turned intensely deep dark blue. The clear reaction mixture was then stirred for $10 \mathrm{~min}$ at elevated temperature, cooled to room temperature, and concentrated in vacuo. The solid black residue was washed with demineralized water $(3 \times 20 \mathrm{~mL})$ and dried under reduced pressure to yield a blue-black powder $(240 \mathrm{mg}, 95 \%)$. Anal. Calcd for $\mathrm{C}_{17} \mathrm{H}_{13} \mathrm{Cl}_{4^{-}}$ $\mathrm{FeN}_{4} \mathrm{O}_{4}$ (534.97): C, 38.17; H, 2.45; N, 10.47. Found: C, 38.08; H, $2.41 ; \mathrm{N}, 10.41$. UV-vis (methanol, $\left.\epsilon\left[\mathrm{M}^{-1} \mathrm{~cm}^{-1}\right]\right): \lambda_{\max }=490$ (1600), $626(2300) \mathrm{nm}$. ESI-MS: $m / z=536.00\left\{[\mathrm{M}+\mathrm{H}]^{+}\right.$, calcd 535.91 $\}$.

[Fe $\left.\left.\mathrm{FII}^{\mathrm{II}} \mathbf{L 2}\right)(\mathbf{t c c})\right](\mathbf{5})$. To a solution of K[L2] (15) (163 mg, $\left.0.44 \mathrm{mmol}\right)$ in hot methanol $(10 \mathrm{~mL})$ was added an orange solution of $\mathrm{Fe}\left(\mathrm{NO}_{3}\right)_{3}$. $9 \mathrm{H}_{2} \mathrm{O}(177 \mathrm{mg}, 0.44 \mathrm{mmol})$ in methanol $(10 \mathrm{~mL})$, and immediately a color change to dark red was observed. This solution was stirred for $10 \mathrm{~min}$ at $50{ }^{\circ} \mathrm{C}$. A solution of $\mathrm{H}_{2} \mathrm{tcc}(109 \mathrm{mg}, 0.44 \mathrm{mmol})$ and 2.5 equiv of $\mathrm{Et}_{3} \mathrm{~N}(154 \mu \mathrm{L})$ in methanol $(8 \mathrm{~mL})$ was added to the hot reaction mixture, and immediately the color of the solution turned intensely deep blue. The reaction mixture was then stirred for $10 \mathrm{~min}$ at elevated temperature and cooled to room temperature upon which a blue precipitate formed. The solution was concentrated in vacuo. The solid blue-black residue was washed with demineralized water $(3 \times$ $20 \mathrm{~mL}$ ) and dried under reduced pressure to yield a blue-black powder (200 mg, 72\%). Anal. Calcd for $\mathrm{C}_{25} \mathrm{H}_{17} \mathrm{Cl}_{4} \mathrm{FeN}_{4} \mathrm{O}_{4}$ (635.08): C, 47.28; H, 2.70; N, 8.82. Found: C, 47.31; H, 2.84; N, 8.73. UV-vis (methanol, $\left.\epsilon\left[\mathrm{M}^{-1} \mathrm{~cm}^{-1}\right]\right): \lambda_{\max }=480(1400), 663(2100) \mathrm{nm}$. ESI-MS: $m / z=$ $636.04\left\{[\mathrm{M}+\mathrm{H}]^{+}\right.$, calcd 635.94\}, $658.02\left\{[\mathrm{M}+\mathrm{Na}]^{+}\right.$, calcd 657.92\}, $673.98\left\{[\mathrm{M}+\mathrm{K}]^{+}\right.$, calcd 674.19$\}$

$\left[\mathrm{Fe}^{\mathrm{III}}(\mathbf{L 3})(\mathbf{t c c})\right](\mathbf{6})$. To a colorless solution of K[L3] (13) (124 mg, $0.32 \mathrm{mmol})$ in hot methanol $(10 \mathrm{~mL})$ was added an orange solution of
$\mathrm{Fe}\left(\mathrm{NO}_{3}\right)_{3} \cdot 9 \mathrm{H}_{2} \mathrm{O}(131 \mathrm{mg}, 0.32 \mathrm{mmol})$ in methanol $(10 \mathrm{~mL})$, and immediately a color change to yellow was observed. This solution was stirred for $10 \mathrm{~min}$ at $50{ }^{\circ} \mathrm{C}$. A solution of $\mathrm{H}_{2} \mathrm{tcc}(80 \mathrm{mg}, 0.32 \mathrm{mmol})$ and 2.5 equiv of $\mathrm{Et}_{3} \mathrm{~N}(113 \mu \mathrm{L})$ in methanol $(8 \mathrm{~mL})$ was added to the hot reaction mixture, and immediately the color of the solution turned intensely deep dark blue. The clear reaction mixture was then stirred for $10 \mathrm{~min}$ at elevated temperature, cooled to room temperature, and concentrated in vacuo. The solid blue-black residue was washed with demineralized water $(3 \times 20 \mathrm{~mL})$ and dried under reduced pressure to yield a blue-black powder (145 mg, 70\%). Crystals suitable for X-ray crystallography were grown by slow evaporation of a solution of $\mathbf{6}$ in $\mathrm{CH}_{2} \mathrm{Cl}_{2}$ /hexanes. Anal. Calcd for $\mathrm{C}_{25} \mathrm{H}_{29} \mathrm{Cl}_{4} \mathrm{FeN}_{4} \mathrm{O}_{4}$ (647.18): C, 46.40; H, 4.52; N, 8.66. Found: C, 46.24; H, 4.41; N, 8.73. UV-vis (methanol, $\left.\epsilon\left[\mathrm{M}^{-1} \mathrm{~cm}^{-1}\right]\right): \lambda_{\max }=492(1600), 667(2400) \mathrm{nm}$. ESI-MS: $\mathrm{m} / z=$ $648.15\left\{[\mathrm{M}+\mathrm{H}]^{+}\right.$, calcd 648.03\}, $670.16\left\{[\mathrm{M}+\mathrm{Na}]^{+}\right.$, calcd 670.02\}, $686.10\left\{[\mathrm{M}+\mathrm{K}]^{+}\right.$, calcd 685.99$\}$.

[Fe $\left.{ }^{\text {III }}(\mathbf{L 1})(\mathbf{d t b c})\right](\mathbf{7})$. To a solution of K[L1] (14) $(147 \mathrm{mg}, 0.54$ $\mathrm{mmol})$ in hot, methanol $(10 \mathrm{~mL})$ was added an orange solution of $\mathrm{Fe}$ $\left(\mathrm{NO}_{3}\right)_{3} \quad 9 \mathrm{H}_{2} \mathrm{O}(218 \mathrm{mg}, 0.54 \mathrm{mmol})$ in methanol $(10 \mathrm{~mL})$, and immediately a color change to red-brown was observed. This solution was stirred for $10 \mathrm{~min}$ at $50{ }^{\circ} \mathrm{C}$. A solution of $\mathrm{H}_{2} \mathrm{dtbc}(120 \mathrm{mg}, 0.54$ $\mathrm{mmol})$ and 2.5 equiv of $\mathrm{Et}_{3} \mathrm{~N}(190 \mu \mathrm{L})$ in methanol $(5 \mathrm{~mL})$ was added to the hot reaction mixture, and immediately the color of the solution turned intensely deep purplish-blue. The clear reaction mixture was then stirred for $10 \mathrm{~min}$ at elevated temperature and concentrated in vacuo. The solid residue was washed with demineralized water $(3 \times$ $20 \mathrm{~mL}$ ) and dried under reduced pressure to yield a purplish-blue powder (195 mg, 71\%). Anal. Calcd for $\mathrm{C}_{25} \mathrm{H}_{33} \mathrm{FeN}_{4} \mathrm{O}_{4}$ (509.40): C, 58.95; H, 6.53; N, 11.00. Found: C, 58.72; H, 6.64; N, 10.87. UVvis (methanol, $\epsilon\left[\mathrm{M}^{-1} \mathrm{~cm}^{-1}\right]$ ): $\lambda_{\max }=490$ (2000), 790 (3000) nm. ESI-MS: $m / z=510.34\left\{[\mathrm{M}+\mathrm{H}]^{+}\right.$, calcd 510.19\}, $532.36\{[\mathrm{M}+$ $\mathrm{Na}]^{+}$, calcd 532.17\}, $548.34\left\{[\mathrm{M}+\mathrm{K}]^{+}\right.$, calcd 548.15\}.

[Fe $\left.{ }^{\mathrm{III}}(\mathbf{L 2})(\mathbf{d t b c})\right](\mathbf{8})$. To a solution of K[L2] (15) (102 mg, 0.27 $\mathrm{mmol})$ in hot methanol $(15 \mathrm{~mL})$ was added an orange solution of $\mathrm{Fe}$ $\left(\mathrm{NO}_{3}\right)_{3} \cdot 9 \mathrm{H}_{2} \mathrm{O}(111 \mathrm{mg}, 0.27 \mathrm{mmol})$ in methanol $(5 \mathrm{~mL})$, and immediately a color change to dark red was observed. This solution was stirred for $10 \mathrm{~min}$ at $50{ }^{\circ} \mathrm{C}$. A solution of $\mathrm{H}_{2} \mathrm{dtbc}(61 \mathrm{mg}, 0.27 \mathrm{mmol})$ and 2.5 equiv of $\mathrm{Et}_{3} \mathrm{~N}(96 \mu \mathrm{L})$ in methanol $(5 \mathrm{~mL})$ was added to the hot reaction mixture, and immediately the color of the solution turned intensely deep purplish-blue. The clear reaction mixture was then stirred for $10 \mathrm{~min}$ at elevated temperature and concentrated in vacuo. The solid residue was washed with demineralized water $(3 \times 20 \mathrm{~mL})$ and dried under reduced pressure to yield a purplish-blue powder (160 mg, 96\%). Anal. Calcd for $\mathrm{C}_{33} \mathrm{H}_{37} \mathrm{FeN}_{4} \mathrm{O}_{4}$ (609.52): C, 65.03; H, 6.12; N, 9.19. Found: C, 64.87; H, 6.21; N, 9.04. UV-vis (methanol, $\epsilon\left[\mathrm{M}^{-1} \mathrm{~cm}^{-1}\right]$ ): $\lambda_{\max }=504$ (2900), $822(4200) \mathrm{nm}$. ESI-MS: $m / z=610.33\{[\mathrm{M}+$ $\mathrm{H}]^{+}$, calcd 610.22$\}$.

[Fe $\left.\mathrm{FII}^{\mathrm{II}}(\mathbf{L 3})(\mathbf{d t b c})\right](\mathbf{9 )}$. To a colorless solution of K[L3] (13) (101 $\mathrm{mg}, 0.26 \mathrm{mmol})$ in hot methanol $(10 \mathrm{~mL})$ was added an orange solution of $\mathrm{Fe}\left(\mathrm{NO}_{3}\right)_{3} \cdot 9 \mathrm{H}_{2} \mathrm{O}(106 \mathrm{mg}, 0.26 \mathrm{mmol})$ in methanol $(10 \mathrm{~mL})$, and immediately a color change to yellow was observed. This solution was stirred for $10 \mathrm{~min}$ at $50{ }^{\circ} \mathrm{C}$. A solution of $\mathrm{H}_{2} \mathrm{dtbc}(59 \mathrm{mg}, 0.26 \mathrm{mmol})$ and 2.5 equiv of $\mathrm{Et}_{3} \mathrm{~N}(92 \mu \mathrm{L})$ in methanol $(8 \mathrm{~mL})$ was added to the hot reaction mixture, and immediately the color of the solution turned intensely deep dark purple-blue. The clear reaction mixture was then stirred for $10 \mathrm{~min}$ at elevated temperature, cooled to room temperature, and concentrated in vacuo. The solid residue was washed with demineralized water $(2 \times 20 \mathrm{~mL})$ and dried under reduced pressure to yield a dark purple-blue powder (102 $\mathrm{mg}, 63 \%)$. UV-vis (methanol, $\left.\epsilon\left[\mathrm{M}^{-1} \mathrm{~cm}^{-1}\right]\right): \lambda_{\max }=(521$ (2400), 807 (3200) $\mathrm{nm}$. ESI-MS: $\mathrm{m} / \mathrm{z}=$ $622.49\left\{[\mathrm{M}+\mathrm{H}]^{+}\right.$, calcd 622.32\}, $644.49\left\{[\mathrm{M}+\mathrm{Na}]^{+}\right.$, calcd 644.30\}.

Oxygenation Reactions and Characterization of Oxygenation Products. In a typical reaction, $25 \mathrm{mg}$ of the $\left[\mathrm{Fe}^{\mathrm{III}}(\mathbf{L})(\mathrm{dtbc})\right]$ complexes were dissolved in $40 \mathrm{~mL}$ of solvent and the blue-purple solution was exposed to air and stirred until the blue-purple color had completely faded and the solution had turned green, after which 1 equiv of internal 
standard was added to the solution. The solvent was then removed in vacuo and the residue was redissolved in $20 \mathrm{~mL}$ of $1 \mathrm{M} \mathrm{HCl}$ to decompose the metal complexes. The aqueous solution was extracted with diethyl ether $(3 \times 20 \mathrm{~mL})$, and the combined organic layers were dried over $\mathrm{MgSO}_{4}$, filtered, and evaporated in vacuo. The products were analyzed by $\mathrm{GC}-\mathrm{MS}$ and ${ }^{1} \mathrm{H}$ NMR. The combined intradiol, extradiol, and quinone products accounted for $>90 \%$ of the dtbc reactant. The products were quantified by ${ }^{1} \mathrm{H}$ NMR (1,3,5-tribromobenzene as internal standard), since the quinone auto-oxidation product could not be accurately detected by GC-MS. Authentic samples of the intradiol products 3,5-di-tert-butyl-1-oxacyclohepta-3,5-diene-2,7-dione and 3,5di-tert-butyl-5-carboxymethyl-2-furanone methyl ester were prepared according to a published procedure. ${ }^{66}$ Authentic samples of the extradiol product isomers 3,5-di-tert-butyl-2-pyrone and 4,6-di-tert-butyl-2pyrone were prepared by reacting $\left[\mathrm{FeCl}(\mathrm{dtbc})\left(\mathrm{Me}_{3}\right.\right.$-tacn) $]$ with air as described by Que et al. ${ }^{43}$ In the experiments with added proton donor, 1 equiv of $\left[\mathrm{Et}_{3} \mathrm{NH}\right] \mathrm{BF}_{4}$ in dichloromethane $(1 \mathrm{~mL})$ was added to the $[\mathrm{Fe}(\mathbf{L})(\mathrm{dtbc})]$ solution. $\left[\mathrm{Et}_{3} \mathrm{NH}\right] \mathrm{BF}_{4}$ was added both before and after exposing the solution to air, and no difference in product distribution was observed.

X-ray Crystal Structure Determination of 6. $\mathrm{C}_{25} \mathrm{H}_{31} \mathrm{Cl}_{4} \mathrm{FeN}_{4} \mathrm{O}_{5}$, $\mathrm{fw}=665.19$, black plate, $0.15 \times 0.15 \times 0.03 \mathrm{~mm}^{3}$, monoclinic, $P 2_{1} / c$ (no. 14), $a=13.5894(3) \AA, \quad b=12.7606(4) \AA, c=18.8030(5) \AA, \beta$ $=117.8399(17)^{\circ}, V=2883.21(13) \AA^{3}, Z=4, D_{x}=1.532 \mathrm{~g} / \mathrm{cm}^{3}, \mu=$ $0.94 \mathrm{~mm}^{-1} .28540$ Reflections were measured on a Nonius Kappa CCD diffractometer with rotating anode (graphite monochromator, $\lambda=$ $0.71073 \AA)$ up to a resolution of $(\sin \theta / \lambda)_{\max }=0.60 \AA^{-1}$ at a temperature of $150 \mathrm{~K}$. An absorption correction based on multiple measured reflections was applied ( $0.92-0.97$ correction range). 5255 Reflections were unique $\left(R_{\text {int }}=0.0584\right)$. The structure was solved with
Direct Methods ${ }^{73}$ and refined with SHELXL-9774 against $F^{2}$ of all reflections. Non-hydrogen atoms were refined with anisotropic displacement parameters. All hydrogen atoms were located in the difference Fourier map. Water hydrogen atoms were refined freely with isotropic displacement parameters; all other hydrogen atoms were refined with a riding model. 366 Parameters were refined with no restraints. R1/wR2 $[I>2 \sigma(I)]$ : $0.0375 / 0.0832$. R1/wR2 [all refl.]: 0.0637/0.0947. $S=1.088$. Residual electron density between -0.32 and $0.32 \mathrm{e} / \AA^{3}$. Geometry calculations and checking for higher symmetry were performed with the PLATON program. ${ }^{75}$

Acknowledgment. The work described here was financially supported by the National Research School CombinationCatalysis (P.C.A.B.) and the Council for Chemical Sciences of the Netherlands Organization for Scientific Research $(\mathrm{CW}$ NWO) (M.L., A.L.S.). We thank Dr. S. Bambirra and Dr. A. P. Bruins for their help with the anaerobic ESI-MS measurements.

Supporting Information Available: Experimental details and synthetic scheme for the synthesis of $\mathrm{K}[\mathbf{L 3}]$ and the ESI-MS spectra of complexes $\mathbf{1 - 3}$. Cif file of crystal data collection and refinement parameters, atomic coordinates, bond lengths and angles, and anisotropic displacement parameters for complex 6. This material is available free of charge via the Internet at http://pubs.acs.org.

\section{JA064816X}

(73) Sheldrick, G. M. SHELXS-97. Program for crystal structure solution University of Göttingen: Germany, 1997.

(74) Sheldrick, G. M. SHELXL-97. Program for crystal structure refinement; University of Göttingen: Germany, 1997

(75) Spek, A. L. J. Appl. Crystallogr. 2003, 36, 7-13. 